\title{
Emerging agents that target signaling pathways in cancer stem cells
}

\author{
Yue Yang ${ }^{1 \dagger}$, Xiaoman $\mathrm{Li}^{2 \dagger}$, Ting Wang ${ }^{1}$, Qianqian Guo ${ }^{3}$, Tao Xi $^{1 *}$ (D) and Lufeng Zheng ${ }^{1 *}$
}

\begin{abstract}
Cancer stem cells (CSCS) contribute to the initiation, recurrence, and metastasis of cancer; however, there are still no drugs targeting CSCS in clinical application. There are several signaling pathways playing critical roles in CSC progression, such as the Wnt, Hedgehog, Notch, Hippo, and autophagy signaling pathways. Additionally, targeting the ferroptosis signaling pathway was recently shown to specifically kill CSCs. Therefore, targeting these pathways may suppress CSC progression. The structure of small-molecule drugs shows a good spatial dispersion, and its chemical properties determine its good druggability and pharmacokinetic properties. These characteristics make small-molecule drugs show a great advantage in drug development, which is increasingly popular in the market. Thus, in this review, we will summarize the current researches on the small-molecule compounds suppressing CSC progression, including inhibitors of Wnt, Notch, Hedgehog, and autophagy pathways, and activators of Hippo and ferroptosis pathways. These small-molecule compounds emphasize CSC importance in tumor progression and propose a new strategy to treat cancer in clinic via targeting CSCS.
\end{abstract}

Keywords: Cancer stem cells, Small-molecule compounds, Wht, Hedgehog, Notch, Hippo, Autophagy, Ferroptosis

\section{Background}

Although traditional therapeutic methods can reduce tumor volume extensively, cancer recurrence and metastasis always occur [1]. CSCs constitute a small portion of cancer cells, but they show resistance to chemotherapy and radiotherapy. Most conventional treatment methods kill cells with a proliferative potential to shrink the tumor but have no effect on stationary CSCs. This action explains why the tumor volume is reduced but the patient survival rate is not improved [2]. Due to their self-renewal ability and therapeutic resistance, CSCs are considered to be the root of tumor growth, recurrence, metastasis, and drug resistance [3]. Notably, because of their plasticity, stationary CSCs may produce cycling CSCs, which contributes to the relapse of cancer [4].

\footnotetext{
* Correspondence: xitao18@hotmail.com; zhlf@cpu.edu.cn

†Yue Yang and Xiaoman Li contributed equally to this work.

'School of Life Science and Technology, Jiangsu Key Laboratory of

Carcinogenesis and Intervention, China Pharmaceutical University, 639 Longmian Road, Nanjing 211198, People's Republic of China

Full list of author information is available at the end of the article
}

Therefore, more specific therapies targeting CSCs may lead to better results, and combining them with the traditional therapeutic methods may even achieve healing [5]. Cancer is a disease caused by disordered cell growth due to genetic mutations. CSCs have the same genetic driver mutations as most cancer cells, but CSCs have developmental characteristics that differ from those of non-stem cells, including differences in epigenetic modifications and gene expression profiles [6]. Many changes in the signaling pathways in CSCs provide a preliminary basis for developing compounds targeting CSCs. Signaling pathways that regulate the self-renewal and differentiation of CSCs include Wnt, Hedgehog (Hh), Notch, and Hippo, and these signaling pathways have been extensively studied $[7,8]$. In addition, the signaling pathways inhibiting the proliferation of CSCs, in newly discovered mechanisms, have also gradually gained attention, and many promising results have been obtained (Fig. 1) [9]. Targeting CSCs with traditional therapy (chemotherapy and radiotherapy) may yield better

C C The Author(s). 2020 Open Access This article is licensed under a Creative Commons Attribution 4.0 International License, which permits use, sharing, adaptation, distribution and reproduction in any medium or format, as long as you give appropriate credit to the original author(s) and the source, provide a link to the Creative Commons licence, and indicate if changes were made. The images or other third party material in this article are included in the article's Creative Commons licence, unless indicated otherwise in a credit line to the material. If material is not included in the article's Creative Commons licence and your intended use is not permitted by statutory regulation or exceeds the permitted use, you will need to obtain permission directly from the copyright holder. To view a copy of this licence, visit http://creativecommons.org/licenses/by/4.0/ The Creative Commons Public Domain Dedication waiver (http://creativecommons.org/publicdomain/zero/1.0/) applies to the data made available in this article, unless otherwise stated in a credit line to the data. 


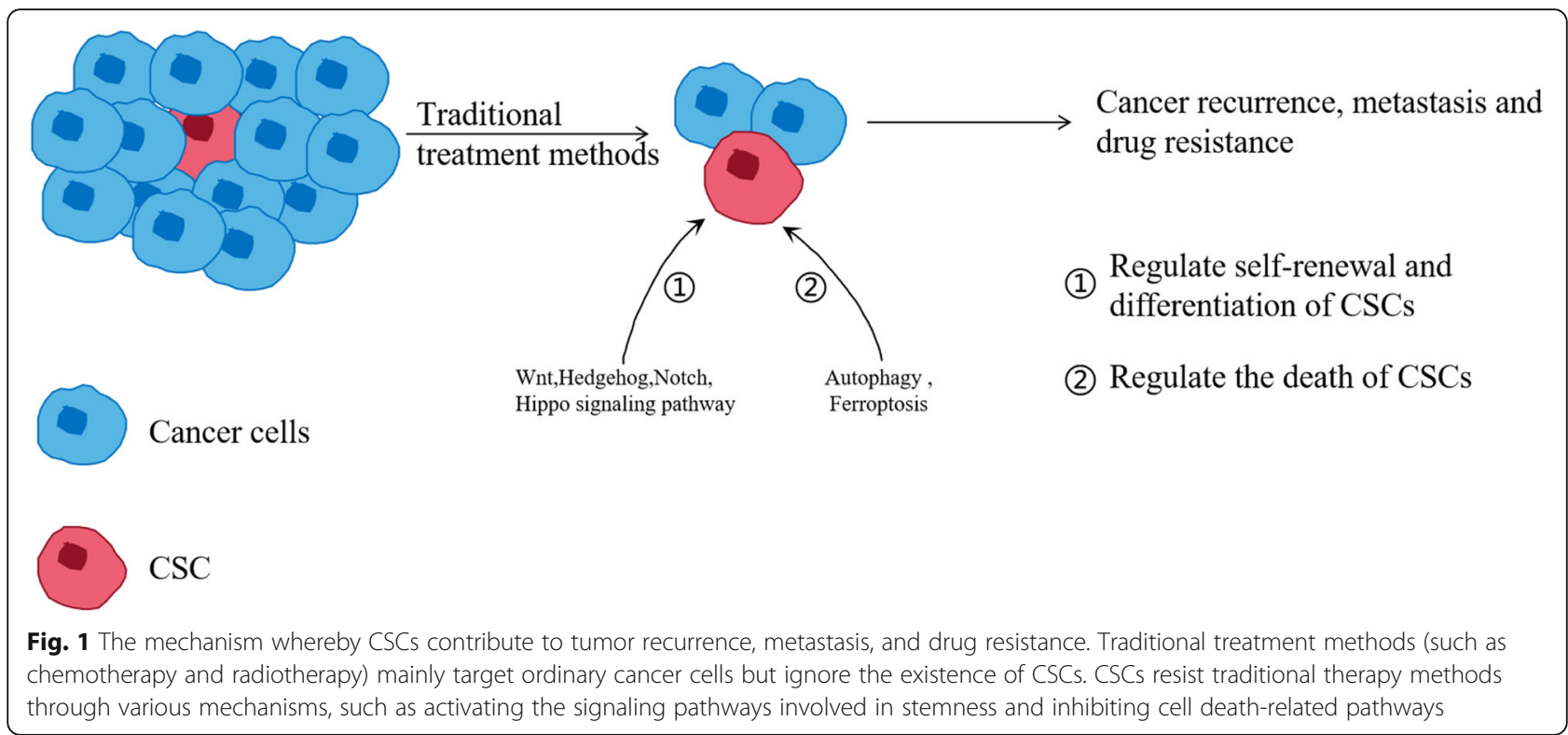

results in controlling tumor growth, preventing cancer recurrence and metastasis, and decreasing drug resistance. Small-molecule compounds targeting CSCs play important role in this attenuation process. This review summarizes the research status of small-molecule compounds that suppress CSC progression, including inhibitors of the Wnt, Notch, Hh, and autophagy signaling pathways and activators of Hippo and ferroptosis signaling pathways, which may provide a basis for a current treatment for cancer.

\section{Signaling pathway regulators}

CSCs display many characteristics of embryonic or tissue stem cells and often show continuous activation of one or more highly conserved signaling pathways related to development and tissue homeostasis. In these signaling pathways, the Wnt, Hh, Notch, and Hippo signaling pathways are associated with CSC self-renewal [10] and have been used to explore new drugs targeting CSCs.

\section{Wnt signaling pathway inhibitors}

The Wnt signaling pathway is highly conserved among species and is divided into the $\beta$-catenin-dependent pathway and noncanonical Wnt pathway. When Wnt ligands bind to the Frizzled protein and low-density lipoprotein receptor-related protein (LRP) coreceptors, they initiate the transduction of $\mathrm{Wnt} / \beta$-catenin signaling, eventually leading to $\beta$-catenin stabilization, nuclear translocation, and activation of target genes [31]. Since the $\beta$-catenin-dependent pathway has been extensively characterized in mammals, regulates the pluripotency of stem cells, and plays a critical role in self-renewal and differentiation ability, it is thought that abnormal activation of the Wnt pathway promotes CSC progression and thus leads to the deterioration and metastasis of cancer. Thus, the inhibition of CSCs can be mediated through this pathway [32, 33] (Table 1).

In clinical trials, several small-molecule compounds have been used to target CSCs through the Wnt $/ \beta$-catenin signaling pathway. For example, LGK-974 (Wnt974) can target porcupine to inhibit the posttranslational acetylation of Wnt, thereby inhibiting Wnt secretion, and it has been reported that Wnt974 can inhibit the proliferation of breast CSCs (BCSCs) [34, 35]. Notably, in a phase I study, Wnt974 was found to be safe and effective in treating triple negative breast cancer (TNBC) (NCT01351103). Niclosamide has been approved by the FDA as an antihelminthic, and as a Wnt/ $\beta$-catenin pathway inhibitor, it has anticancer ability that has been established by various studies. Niclosamide has been shown to selectively target ovarian CSCs [36]. In addition, niclosamide can decrease the population of $\mathrm{ALDH}^{+}$cells by reducing the expression of LRP6 (a Wnt ligand receptor that plays a key role in the $\mathrm{Wnt} / \beta$-catenin pathway) and $\beta$-catenin in basal-like breast cancer [37]. Notably, in a phase II trail, niclosamide was proved to safely and effectively treat colorectal cancer (CRC) [12]. Mechanistically, it can reduce the expression of many signaling components in the $\mathrm{Wnt} / \beta$-catenin signaling pathway, the CSC population, and the selfrenewal ability of CRC cells [38]. Additionally, ONC201, which is in a phase I/II study for patients with advanced cancer (NCT02038699), can inhibit CSC self-renewal and the expression of CSC-related genes in prostate and glioblastoma tumors through suppressing the Wnt signaling pathway [39].

Furthermore, there are many potential small-molecule compounds targeting CSCs through Wnt/ $\beta$-catenin 


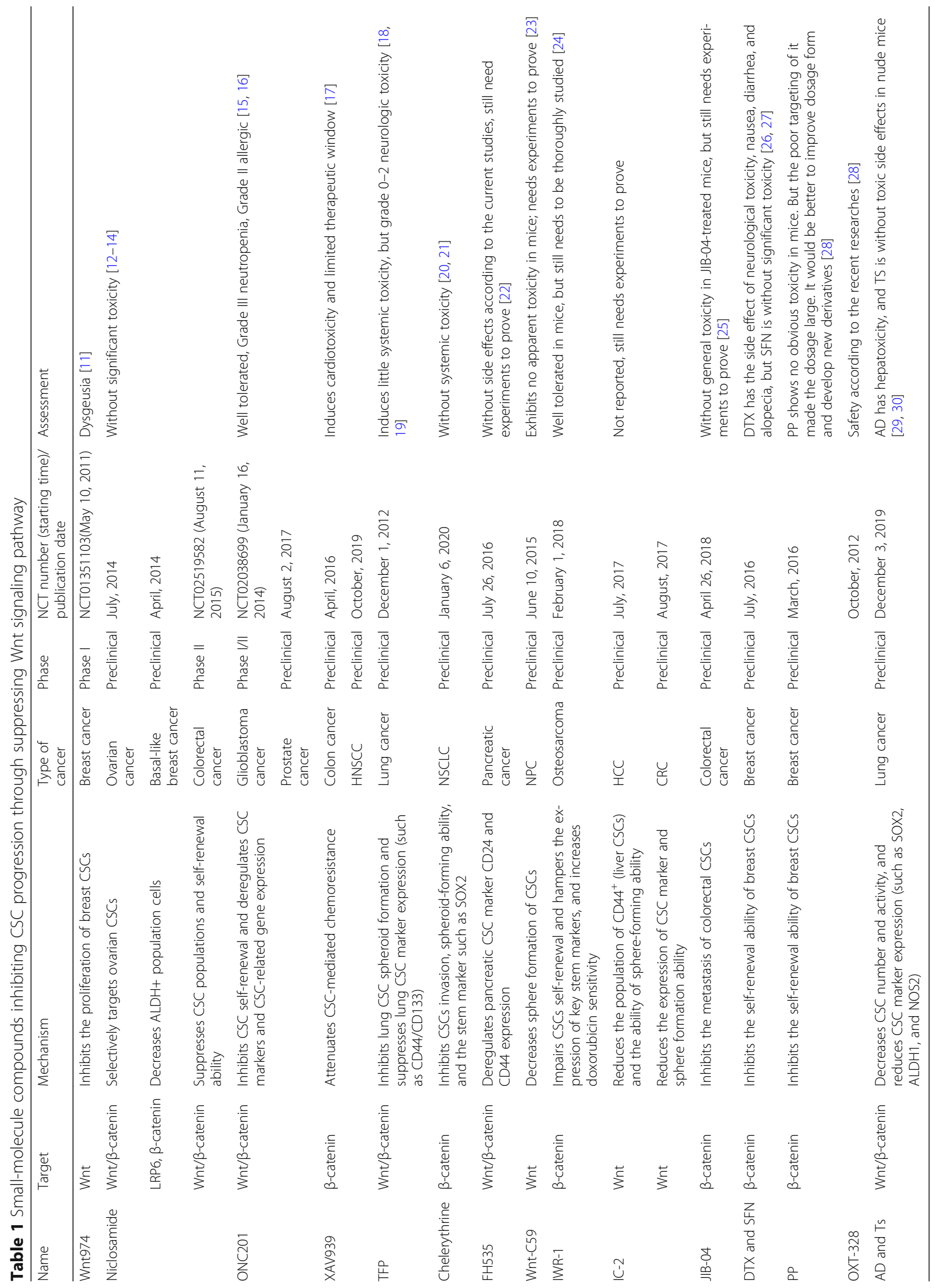


signaling pathway in preclinical experiments. For example, XAV939 can inhibit $\beta$-catenin signaling and thus attenuate CSC progression by interacting with the terminal anchor polymerase-binding domain (TBD) in Axin [40], which can abrogate CSC-mediated chemoresistance in head and neck squamous cell carcinoma (HNSCC) and colon cancer cells $[41,42]$. Trifluoperazine (TFP) is used as an antipsychotic and an antiemetic, and it has been found to inhibit lung CSC spheroid formation ability and suppress lung CSC marker expression (such as CD44/CD133) by inhibiting Wnt/ $\beta$-catenin signaling [43]. Chelerythrine chloride (Chelerythrine) can downregulate $\beta$-catenin and inhibit CSC invasion, spheroidforming ability, and the expression of the stem marker SOX2 in non-small cell lung carcinoma (NSCLC) [44]. FH535 can suppress the expression of the pancreatic CSC marker CD24 and CD44 by inhibiting the Wnt/ $\mathrm{\beta}$ catenin signaling pathway [45]. Wnt-C59 (C59), an inhibitor of Wnt, can decrease the sphere formation ability of CSCs in a dose-dependent manner in nasopharyngeal carcinoma (NPC) [46]. IWR-1, a tankyrase inhibitor, can impair osteosarcoma CSC self-renewal, hamper the expression of key stem markers in osteosarcoma, and increase doxorubicin sensitivity in vivo by inhibiting $\beta$ catenin translocation [24]. IC-2, a novel small-molecule Wnt inhibitor, can reduce the population of $\mathrm{CD} 44^{+}$ (liver CSCs) and the sphere-forming ability of hepatocellular carcinoma (HCC) cells [47]. It can also reduce the expression of CSC markers and the sphere formation ability in CRC. In addition, it can increase the sensitivity of 5-FU in the DLD-1 CRC cell line [48]. JIB-04, a selective inhibitor of histone demethylase, can inhibit the metastasis of colorectal CSCs by regulating the recruitment of $\beta$-catenin [49]. The combination of docetaxel (DTX) and sulforaphane (SFN), pyrvinium pamoate (PP), and phosphor-sulindac (OXT-328) can inhibit CSC self-renewal ability, the EMT (epithelial-mesenchymal transition), and drug resistance by decreasing $\beta$-catenin expression in BCSCs [50-52]. Additionally, actinomycin $\mathrm{D}$ (AD) and telmisartan (TS) can also decrease the CSC number and activity and reduce CSC marker expression (such as SOX2, ALDH1, and NOS2) in lung cancer by inhibiting the Wnt- $\beta /$ catenin signaling pathway [53].

\section{Notch signaling pathway inhibitors}

The Notch signaling pathway is an evolutionarily conserved pathway that is closely related to all aspects of cancer biology including CSC progression, angiogenesis, and tumor immunity [54]. The Notch pathway mainly consists of Notch receptors (Notch 1-4) and Notch ligands (Jagged 1, Jagged 2, delta-like ligand (DLL) -1, DLL-3, and DLL-4). When the receptors bind to the ligands, the Notch intracellular domain (NICD) is released into the nucleus through three cleavage processes mediated by $\gamma$-secretase, thereby activating the transcription of Notch target genes (Hes-1 and Hey-1) [55]. The activation of the Notch signaling pathway promotes tumor proliferation and metastasis; in contrast, inhibition of this pathway can eliminate CSCs and increase drug sensitivity. Therefore, genes in the Notch signaling pathway may represent potential cancer therapeutic targets [56]. Notch inhibitors can be used alone or in combination with chemotherapy agents to treat cancer and prevent recurrence [57].

Currently, inhibitors targeting the Notch signaling pathway mostly target $\gamma$-secretase or Notch ligands (Table 2). For example, MK-0752, a $\gamma$-secretase inhibitor, can decrease the population of $\mathrm{CD} 44^{+} / \mathrm{CD} 24^{-}$and $\mathrm{ALDH}^{+}$, reduce mammosphere-forming efficiency, and inhibit tumor regeneration in BCSCs [63]. In a phase I study, the combined use of MK-0752 with docetaxel increased MK-0752-induced anti-BCSC ability and improved the efficiency of docetaxel in treating breast cancer (NCT00645333). PF-03084014, another $\gamma$ secretase inhibitor, can inhibit CSC self-renewal and proliferation and induce CSC differentiation by targeting Notch signaling pathways in HCC [64]. PF-03084014 can also decrease the $\mathrm{CD} 44^{+} / \mathrm{CD} 24^{-}$and $\mathrm{ALDH}^{+}$populations by suppressing N1ICD cleavage and the expression of Hes-1 and Hey-1 in pancreatic cancer [65]. In a phase II trail, PF-03084014 combined with gemcitabine and nab-paclitaxel increased the overall survival of patients with metastatic pancreatic adenocarcinoma (NCT02109445) compared to that of patients treated with PF-03084014. When combined with docetaxel, PF03084014 can increase docetaxel efficiency against breast cancer; this combination is in a phase I study (NCT01876251). Mechanistically, PF-03084014 can di-

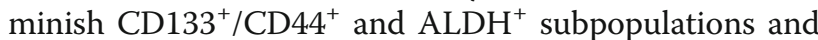
eliminate BCSCs by targeting the Notch signaling pathway, thereby decreasing drug resistance [66].

Additionally, the $\gamma$-secretase inhibitor RO4929097 can significantly inhibit Notch target genes Hes1 and Hey1, and it is in a phase II clinical setting to treat breast cancer, ovarian cancer, and renal cell carcinoma [67]. The combination of RO4929097 and 5-FU can decrease the proportion of the CSC subgroup with insulinomas (INS) [68]. DAPT (GSI-IX) is a new type of Notch1 inhibitor that was initially used to treat Alzheimer's disease, and increasing number of studies have shown that it can inhibit CSCs [69]. Studies have demonstrated that DAPT can inhibit the proliferation and self-renewal ability of leukemia stem cells (LSCs) and ovarian CSCs [70, 71]. Additionally, quinomycin A can inhibit pancreatic cancer microsphere formation, stem marker expression, and CSC number by decreasing the expression of Notch ligands [72]. 
Table 2 Small-molecule compounds inhibiting CSC progression through suppressing Notch signaling pathway

\begin{tabular}{|c|c|c|c|c|c|c|}
\hline Name & Target & Mechanism & $\begin{array}{l}\text { Type of } \\
\text { cancer }\end{array}$ & Phase & $\begin{array}{l}\text { NCT number (starting time)/ } \\
\text { publication date }\end{array}$ & Assessment \\
\hline MK-0752 & $\gamma$-secretase & $\begin{array}{l}\text { Decreases the population of } \mathrm{CD}^{+} 4^{+} / \mathrm{CD} 24^{-} \\
\text {and } \mathrm{ALDH}^{+} \text {, reduces mammosphere-forming } \\
\text { efficiency, and inhibits tumor regeneration in } \\
\text { BCSCs }\end{array}$ & $\begin{array}{l}\text { Breast } \\
\text { cancer }\end{array}$ & Phase I & $\begin{array}{l}\text { NCT00645333 } \\
\text { (March 27, 2008) }\end{array}$ & $\begin{array}{l}\text { Well tolerated, but } \\
\text { exists dose- } \\
\text { limiting toxicity } \\
\text { (DLT) [58] }\end{array}$ \\
\hline \multirow[t]{3}{*}{ PF-03084014 } & $\gamma$-secretase & $\begin{array}{l}\text { Inhibits CSC self-renewal and proliferation, } \\
\text { and induces CSCs differentiation }\end{array}$ & $\mathrm{HCC}$ & Preclinical & August, 2017 & \multirow{3}{*}{$\begin{array}{l}\text { Induces } \\
\text { gastrointestinal } \\
\text { toxicity and exists } \\
\text { DLT [59] }\end{array}$} \\
\hline & $\begin{array}{l}\text { N1ICD, } \\
\text { Hes-1, and } \\
\text { Hey-1 }\end{array}$ & $\begin{array}{l}\text { Decreases CD44+/CD24- and ALDH+ } \\
\text { population }\end{array}$ & $\begin{array}{l}\text { Pancreatic } \\
\text { cancer }\end{array}$ & Phase II & NCT02109445(April 9, 2014) & \\
\hline & Notch & $\begin{array}{l}\text { Diminishes } \mathrm{CD}_{133^{+}} / \mathrm{CD}_{4} 4^{+} \text {and } \mathrm{ALDH}^{+} \\
\text {subpopulations and eliminates } \mathrm{CSCS}\end{array}$ & $\begin{array}{l}\text { Breast } \\
\text { cancer }\end{array}$ & Phase I & $\begin{array}{l}\text { NCT01876251( } \\
\text { June } 12,2013)\end{array}$ & \\
\hline RO4929097 & $\gamma$-secretase & $\begin{array}{l}\text { Combined with 5-FU can decrease the pro- } \\
\text { portion of CSC subgroup }\end{array}$ & INS & Preclinical & February, 2018 & $\begin{array}{l}\text { Fatigue is the } \\
\text { most common } \\
\text { toxicities, but it } \\
\text { has DLT [60] }\end{array}$ \\
\hline \multirow[t]{2}{*}{ DAPT } & \multirow[t]{2}{*}{ Notch1 } & $\begin{array}{l}\text { Inhibits the proliferation of LSCs and } \\
\text { regulates LSC self-renewal }\end{array}$ & Leukemia & Preclinical & December, 2006 & \multirow{2}{*}{$\begin{array}{l}\text { Induces low } \\
\text { toxicity in cell and } \\
\text { mice }[61]\end{array}$} \\
\hline & & $\begin{array}{l}\text { Inhibits the self-renewal ability of ovarian } \\
\text { CSCs and the expression of stem markers }\end{array}$ & $\begin{array}{l}\text { Ovarian } \\
\text { cancer }\end{array}$ & Preclinical & June, 2011 & \\
\hline Quinomycin A & $\begin{array}{l}\text { Notch } \\
\text { ligands }\end{array}$ & $\begin{array}{l}\text { Inhibits pancreatic cancer microsphere } \\
\text { formation, the stem marker and the number } \\
\text { of CSCs }\end{array}$ & $\begin{array}{l}\text { Pancreatic } \\
\text { cancer }\end{array}$ & Preclinical & January 19, 2016 & $\begin{array}{l}\text { Induces } \\
\text { gastrointestinal } \\
\text { toxicity [62] }\end{array}$ \\
\hline
\end{tabular}

\section{Hh signaling pathway inhibitors}

The Classical Hh signaling pathway is critical for embryonic development. The Hh signaling pathway regulates the self-renewal of CSCs and tissue homeostasis in cancer [80]. When extracellular $\mathrm{Hh}$ ligands $(\mathrm{SHh}, \mathrm{IH}$, and $\mathrm{DHh}$ ) bind to $\mathrm{PTCH}$, the inhibition of $\mathrm{PTCH}$ on Smoothened (SMO) is decreased, thereby GlI is translocated to the nucleus and induces the transcription of target genes [81]. Abnormal activation of the Hh signaling pathway is a crucial driver of breast cancer, prostate cancer, NSCLC, gastric cancer, and hematopoietic malignancies [82]. Hh signaling pathway inhibitors have been proven to be effective in early clinical trials. In addition, the development of $\mathrm{Hh}$ inhibitors has drawn significant interest for anticancer drug development. Recently, it has been reported that inhibition of the Hh signaling pathway can inhibit the self-renewal and drug resistance of pancreatic and breast CSCs [83, 84] (Table 3).

For example, ciclesonide was approved by the FDA to treat asthma, and it was found that ciclesonide can inhibit the growth of lung CSCs through Hh signalingmediated SOX2 regulation [85]. Sonidegib, an SMO antagonist, was approved by the FDA for the treatment of advanced basal cell carcinoma [86]. Recently, it was shown that sonidegib can downregulate the expression of CSC markers and increase the sensitivity of TNBC to paclitaxel, thus improving patient survival and reducing metastasis [87]. In addition, in a phase I study, sonidegib obtained a better result in advanced TNBC when it was combined with docetaxel (NCT02027376). Vismodegib
(GDC-0449), another SMO inhibitor, was approved by the FDA to treat basal cell carcinoma [88]. Recently, many studies have found that vismodegib can inhibit BCSC self-renewal and mammosphere formation [89]. In a phase II trial, vismodegib was added to neoadjuvant chemotherapy for TNBC patients (NCT02694224). It can also suppress pancreatic CSC proliferation and survival by inhibiting $\mathrm{Hh}$ signaling pathways [90]. In a phase II trial, vismodegib combined with gemcitabine and nab-paclitaxel was used against untreated metastatic pancreatic cancer [91]. In another phase Ib/II trial, vismodegib plus gemcitabine was used to treat metastatic pancreatic cancer [92]. Additionally, vismodegib decreased the stem markers (such as CD44 and ALDH) of colon CSCs [93], and it was used to treat untreated metastatic CRC in a phase II trial [94]. These results suggest that vismodegib can target CSCs through the $\mathrm{Hh}$ signaling pathway. Furthermore, glasdegib (PF04449913), an Hh signaling pathway inhibitor, was approved by the FDA to treat acute myeloid leukemia [73]. Glasdegib can attenuate the potential of leukemiainitiation and increase the sensitivity of LSCs to chemotherapy by inhibiting the $\mathrm{Hh}$ signaling pathway [95]. Cyclopamine is a natural compound that can specifically target SMO and inhibit the Hh signaling pathway [96], and it was reported that cyclopamine can inhibit bladder CSC self-renewal [97]. GANT61, another Hh inhibitor, can decrease the CSC population by downregulating the expression of GLI1 and GLI2 in ER (estrogen receptor)positive breast cancer [98]. 
Table 3 Small-molecule compounds inhibiting CSC progression through suppressing Hh signalling pathway

\begin{tabular}{|c|c|c|c|c|c|c|}
\hline Name & Target & Mechanism & $\begin{array}{l}\text { Type of } \\
\text { cancer }\end{array}$ & Phase & $\begin{array}{l}\text { NCT number } \\
\text { (starting time)/ } \\
\text { publication date }\end{array}$ & Assessment \\
\hline Glasdegib & $\mathrm{Hh}$ & $\begin{array}{l}\text { Attenuates the potential of } \\
\text { leukemia-initiation and in- } \\
\text { creases the sensitivity of LSCs } \\
\text { to chemotherapy }\end{array}$ & Leukemia & Approved & $\begin{array}{l}\text { November 21, } \\
2018\end{array}$ & $\begin{array}{l}\text { Induces common side effect of } \\
\text { chemotherapy drugs such as fatigue, } \\
\text { nausea, and febrile neutropenia, but also } \\
\text { has embryo-fetal toxicity [73] }\end{array}$ \\
\hline Sonidegib & SMO & $\begin{array}{l}\text { Downregulates the } \\
\text { expression of CSC markers } \\
\text { and increases the sensitivity } \\
\text { to paclitaxel }\end{array}$ & $\begin{array}{l}\text { Breast } \\
\text { cancer }\end{array}$ & Phase I & $\begin{array}{l}\text { NCT02027376 } \\
\text { (January 6, 2014) }\end{array}$ & $\begin{array}{l}\text { Induces myalgia, fatigue, and abnormal } \\
\text { hepatic function, and gastrointestinal } \\
\text { toxicity and alopecia are related to the } \\
\text { dose of Sonidegib }[74,75]\end{array}$ \\
\hline \multirow[t]{3}{*}{ Vismodegib } & SMO & $\begin{array}{l}\text { Inhibits BCSC self-renewal } \\
\text { and mammosphere } \\
\text { formation }\end{array}$ & $\begin{array}{l}\text { Breast } \\
\text { cancer }\end{array}$ & Phase II & $\begin{array}{l}\text { NCT02694224 } \\
\text { (February 29, 2016) }\end{array}$ & DLT, hyperbilirubinemia [76] \\
\hline & & $\begin{array}{l}\text { Suppresses pancreatic CSC } \\
\text { proliferation and survival }\end{array}$ & $\begin{array}{l}\text { Pancreatic } \\
\text { cancer }\end{array}$ & Phase II & $\begin{array}{l}\text { NCT01064622 } \\
\text { (February 8, 2010) }\end{array}$ & \\
\hline & & $\begin{array}{l}\text { Decreases the stem markers } \\
\text { (such as CD44 and ALDH) of } \\
\text { colon CSCs }\end{array}$ & $\begin{array}{l}\text { Colorectal } \\
\text { cancer }\end{array}$ & Phase II & $\begin{array}{l}\text { NCT00636610 } \\
\text { (March 14, 2008) }\end{array}$ & \\
\hline Ciclesonide & $\mathrm{Hh}$ & $\begin{array}{l}\text { Inhibits the growth of lung } \\
\text { CSCs }\end{array}$ & $\begin{array}{l}\text { Lung } \\
\text { cancer }\end{array}$ & Preclinical & February 4, 2020 & $\begin{array}{l}\text { Well tolerated, but as corticosteroid, it } \\
\text { may inhibit bone growth [77] }\end{array}$ \\
\hline Cyclopamine & SMO & $\begin{array}{l}\text { Inhibits bladder CSC self- } \\
\text { renewal }\end{array}$ & $\begin{array}{l}\text { Bladder } \\
\text { cancer }\end{array}$ & Preclinical & March 1, 2016 & $\begin{array}{l}\text { Induces holoprosencephaly, dystonia, and } \\
\text { lethargy in rodents [78] }\end{array}$ \\
\hline GANT61 & GLI1 and GLI2 & $\begin{array}{l}\text { Decreases the CSC } \\
\text { population }\end{array}$ & $\begin{array}{l}\text { Breast } \\
\text { cancer }\end{array}$ & Preclinical & May, 2017 & $\begin{array}{l}\text { No side effects in the mice according to } \\
\text { the current studies [79] }\end{array}$ \\
\hline
\end{tabular}

\section{Hippo pathway activators}

The Hippo signaling pathway plays an essential role in CSC self-renewal, the EMT, and drug resistance. Upon activation of the Hippo signaling pathway, MST1/2 phosphorylate and activate LATS1/2. Then, LATS1/2 inactivate YAP/TAZ, which was subsequently translocated into the cytoplasm, and thus inhibits the expression of TEAD (TEA domain family member)-mediated genes, thereby suppressing CSC progression [106]. In contrast, inhibition of the Hippo signaling pathway activates YAP/ TAZ, conferring CSC-like characteristics to the cell and leading to tumorigenesis [107]. YAP/TAZ-TEAD acts as a tumor promoter in the Hippo signaling pathway, while the other members of the Hippo signaling pathway are mostly tumor suppressor genes. Thus, targeting YAP/ TAZ may serve as a strategy to inhibit CSCs (Table 4).

For instance, verteporfin is a photosensitizer approved by the FDA, and it has garnered increasing interest for its anticancer role in gastric and esophageal cancer. Verteporfin can inhibit the transcriptional activity of YAP/TAZTEAD, reduce the expression of CSC markers, and suppress CSC proliferation [108, 109]. Evodiamine (Evo), which is isolated from the Chinese herb Evodia rutaecarpa Benham, can activate MST1/2-mediated phosphorylation of LATS1/2, which leads to YAP/TAZ phosphorylation and prevents YAP/TAZ translocation from the cytoplasm into the nucleus, and it has been shown that Evo can inhibit the proliferation of colon CSCs $[110,111]$. Additionally, tanshinone IIA and limonin, which are extracted from
Chinese herbs, have been shown to attenuate the stemness of cervical carcinoma stem cells by inhibiting the cytoplasmic-nuclear translocation of YAP $[112,113]$. Moreover, statins such as fluvastatin can reduce the expression of CD44 by accelerating YAP phosphorylation, thereby reducing the characteristics of malignant mesothelioma stem cells and drug resistance [114]. Atorvastatin, another stain, can target TAZ in breast cancer, and is in a phase II trial (NCT02416427). Notably, atorvastatin can decrease the stemness of MDA-MB 231 cells, as evident by the decrease in the $\mathrm{CD} 44^{+} / \mathrm{CD} 24^{-}$subpopulation of cells by inducing LATS1 expression and downregulating the expression of YAP/TAZ [115].

Recently, a new type of YAP inhibitor, CA3, was screened from a chemical library and found to attenuate the transcriptional activity of YAP/TEAD, and CA3 shows an excellent ability to target CSCs and inhibit tumor growth, as evident by its role in suppressing tumor sphere formation and reducing the proportion of $\mathrm{ALDH} 1^{+}$cells [104]. In addition, the antipsychotic drug chlorpromazine (CPZ) can kill breast cancer and BCSCs, which were characterized by inhibited tumor microsphere-formation and stem marker expression through promoting YAP degradation [116].

\section{Selective inducers of signaling pathways that contribute to cell death}

According to measurable biochemical characteristics and molecular mechanisms, signaling pathways contributing 
Table 4 Small-molecule compounds inhibiting CSC progression through activating Hippo pathway

\begin{tabular}{|c|c|c|c|c|c|c|}
\hline Name & Target & Mechanism & Type of cancer & Phase & $\begin{array}{l}\text { NCT number (starting time)/ } \\
\text { publication date }\end{array}$ & Assessment \\
\hline \multirow[t]{2}{*}{ Verteporfin } & YAP/TAZ & $\begin{array}{l}\text { Reduces the expression of CSC } \\
\text { markers and suppresses CSC } \\
\text { proliferation }\end{array}$ & $\begin{array}{l}\text { Gastric and } \\
\text { esophageal } \\
\text { cancer }\end{array}$ & Preclinical & August 1, 2014 & $\begin{array}{l}\text { Without visible toxicity } \\
\text { in the mice [99] }\end{array}$ \\
\hline & & & gastric cancer & Preclinical & Apr 15, 2020 & \\
\hline Evodiamine & LATS1/2 & Inhibits the proliferation of colon CSCS & Colon cancer & Preclinical & December 10, 2019 & $\begin{array}{l}\text { Induces low toxicity } \\
\text { and still needs much } \\
\text { experiments to prove } \\
{[100]}\end{array}$ \\
\hline Fluvastatin & YAP & $\begin{array}{l}\text { Reduces the expression of CD } 44 \text { and } \\
\text { the characteristics of malignant } \\
\text { mesothelioma stem cells }\end{array}$ & $\begin{array}{l}\text { Malignant } \\
\text { mesothelioma }\end{array}$ & Preclinical & January 28, 2017 & $\begin{array}{l}\text { Without any genotoxic, } \\
\text { and relatively safe in } \\
\text { patients }[101,102]\end{array}$ \\
\hline Atorvastatin & TAZ & $\begin{array}{l}\text { Decreases MDA-MB } 231 \text { cells } \\
\text { stemness-related features (such as the } \\
\text { decrease of CD44+/CD24- subpopula- } \\
\text { tion of cells) }\end{array}$ & Breast cancer & Phase II & $\begin{array}{l}\text { NCT02416427(April 15, } \\
\text { 2015) }\end{array}$ & Muscle loss [103] \\
\hline CA3 & YAP/TEAD & $\begin{array}{l}\text { Suppresses tumor microsphere, } \\
\text { formation and reduces the proportion } \\
\text { of } A L D H 1+\text { cells }\end{array}$ & $\begin{array}{l}\text { Esophageal } \\
\text { adenocarcinoma }\end{array}$ & Preclinical & February, 2018 & $\begin{array}{l}\text { Without apparent } \\
\text { toxicity in mice } \\
\text { according to the } \\
\text { current studies [104] }\end{array}$ \\
\hline$C P Z$ & YAP & $\begin{array}{l}\text { Inhibits tumor microsphere-formation } \\
\text { and stem marker expression }\end{array}$ & Breast cancer & Preclinical & April 1, 2019 & $\begin{array}{l}\text { Induces fatal hepatic } \\
\text { failure [105] }\end{array}$ \\
\hline
\end{tabular}

to cell death mainly include apoptosis, autophagy, necroptosis, and ferroptosis. Cancer cells also undergo multiple forms of cell death during tumor development, including apoptosis, autophagy, and necrosis. Recently, ferroptosis has been shown to play a critical role in the development of cancer and may be a beneficial anticancer treatment strategy, which has gradually gained attention. Because classic apoptosis-inducing drugs have a poor effect on CSCs, current research is more intent on inhibiting CSCs by inducing autophagy and ferroptosis, which can effectively inhibit cancer recurrence and metastasis

\section{Autophagy and CSCs}

Autophagy is a self-digesting mechanism in which proteins, lipids, and damaged organelles (such as mitochondria) are sequestered into vesicles called autophagosomes for degradation and recycling. Under physiological conditions, autophagy is critical for maintaining cell homeostasis and controlling protein and organelle quality. High levels of autophagy often occur in CSCs. Autophagy can help CSCs maintain their diversity and overcome low nutrients and hypoxia in the tumor microenvironment; therefore, it promotes CSCs to metastasis, drug resistance, and immune surveillance evasion [122]. Recently, autophagy was associated with CSC progression in breast cancer, NSCLC, prostate cancer, leukemia, gastric cancer, and myeloma, and its dysfunction affects the self-renewal ability of CSCs. Therefore, autophagy can be used as a CSC target. Although promotion of autophagy in CSCs is specific, different types, periods, and microenvironments have been shown to inhibit CSC progression through autophagy. For example, in some acute myeloid leukemias, many autophagy-related genes are mutated or downregulated in patients [123]. Therefore, currently, the compounds targeting autophagy mostly inhibit the autophagy of CSCs to suppress CSC progression (Table 5).

For example, chloroquine (CQ) is widely used in clinical antimalarial drugs and can be used in combination with anticancer drugs to treat cancer. CQ can effectively target CSCs by inhibiting autophagy, which causes the destruction of mitochondrial structures and doublestranded DNA, and the combination of CQ and carboplatin may be a useful adjuvant drug for treating TNBC [124]. CQ can inhibit the expression of stemness markers such as CD133 and decrease the proportions of CSCs, subsequently enhancing the efficacy of cisplatin against NSCLC by inhibiting autophagy [125]. In a phase II study, CQ inhibited breast cancer (NCT02333890). In addition, hydroxychloroquine (HCQ), a derivative of $\mathrm{CQ}$, shows a stronger anticancer ability by targeting autophagy [126]. Additionally, the combination of HCQ and imatinib (IM) can effectively eliminate LSCs in chronic myeloid leukemia, and it is in a phase II trial [127]. A high dose of pantoprazole, a proton pump inhibitor (PPI), can affect docetaxel resistance in metastatic castration-resistant prostate cancer (mCRPC) by inhibiting autophagy, and it is in a phase II trial [128]. Moreover, pantoprazole can inhibit the chemoresistance of gastric CSCs [129]. Therefore, pantoprazole may target CSCs by inhibiting autophagy.

Moreover, concanamycin A is a selective inhibitor of V-ATPase that can inhibit the degradation of 
Table 5 Small-molecule compounds targeting autophagy to inhibit CSCs

\begin{tabular}{|c|c|c|c|c|c|c|}
\hline Name & Target & Mechanism & $\begin{array}{l}\text { Type of } \\
\text { cancer }\end{array}$ & Phase & $\begin{array}{l}\text { NCT number (starting } \\
\text { time)/publication date }\end{array}$ & Assessment \\
\hline \multirow[t]{2}{*}{$\mathrm{CQ}$} & Autophagy & Targets CSCs by inhibiting autophagy & $\begin{array}{l}\text { Breast } \\
\text { cancer }\end{array}$ & Phase II & $\begin{array}{l}\text { NCT02333890 } \\
\text { (January } 7,2015 \text { ) }\end{array}$ & $\begin{array}{l}\text { Induces } \\
\text { cardiotoxicity [117] }\end{array}$ \\
\hline & Autophagy & $\begin{array}{l}\text { Inhibits the stemness marker of CD133+ and } \\
\text { decreases the CSC proportions }\end{array}$ & NSCLC & Preclinical & December, 2019 & \\
\hline $\mathrm{HCQ}$ & Autophagy & Eliminates LSCS & Leukemia & Phase II & $\begin{array}{l}\text { NCT00771056 } \\
\text { (October 10, 2008) }\end{array}$ & $\begin{array}{l}\text { Induces retinal } \\
\text { toxicity [118] }\end{array}$ \\
\hline \multirow[t]{2}{*}{ Pantoprazole } & Autophagy & Inhibits autophagy & $\begin{array}{l}\text { Prostate } \\
\text { cancer }\end{array}$ & Phase II & $\begin{array}{l}\text { NCT01748500 } \\
\text { (December 12, 2012) }\end{array}$ & $\begin{array}{l}\text { DLT, grade } 3 \text { to } 4 \\
{[119]}\end{array}$ \\
\hline & $\begin{array}{l}\mathrm{EMT} / \beta- \\
\text { catenin }\end{array}$ & $\begin{array}{l}\text { Inhibits the chemoresistance of gastric cancer } \\
\text { stem cells }\end{array}$ & $\begin{array}{l}\text { Gastric } \\
\text { cancer }\end{array}$ & Preclinical & December, 2016 & \\
\hline 3-MA & Autophagy & $\begin{array}{l}\text { Reduces the resistance of mesenchymal stem } \\
\text { cells }\end{array}$ & Myeloma & Preclinical & September, 2017 & $\begin{array}{l}\text { No significant side } \\
\text { effect [120] }\end{array}$ \\
\hline Rott & Autophagy & $\begin{array}{l}\text { Induces autophagy leading to breast CSC } \\
\text { death }\end{array}$ & $\begin{array}{l}\text { Breast } \\
\text { cancer }\end{array}$ & Preclinical & December 23, 2013 & $\begin{array}{l}\text { Without toxicity in } \\
\text { the mice [121] }\end{array}$ \\
\hline
\end{tabular}

autolysosomes but has no effect on the formation of lysosomes; therefore, lysosomal degradation inhibitors may not reduce the rate of autophagosome-mediating chelation in destroying mitochondria. In this situation, some mitochondrial-dependent drugs may reduce the efficiency of inhibitors on CSCs; therefore, targeting early autophagy such as with VPS34 or ULK1 inhibitors may lead to better results. In addition, 3-methyladenine (3MA) can prevent the formation of autolysosomes and reduce the resistance of mesenchymal stem cells; therefore, it can provide new treatment strategies for patients with multiple myeloma resistance [130]. Rottlerin (Rott), an active molecule that is isolated from Mallotus philippensis, is used in the treatment of allergies and helminthiasis and can induce autophagy, leading to BCSC death [131]. However, it is noteworthy that, although autophagy-targeting therapy has fewer side effects on normal cells than do conventional therapies, it also has some unknown effects that remain to be explored.

\section{Ferroptosis and CSCs}

Ferroptosis is a new type of programmed cell death that is different from apoptosis, necrosis, and autophagy at the morphological and biochemical levels. It is induced by the accumulation of iron and lipid peroxidation caused by reactive oxygen species (ROS). The destruction of iron homeostasis and uncontrolled lipid peroxidation are two key features of ferroptosis [132]. The regulation of intracellular iron homeostasis is mainly regulated by IRP2 (iron regulatory protein 2). IRP2 can bind to iron-responsive elements (IREs) in mRNA 5'and 3'-untranslated regions (UTRs) to inhibit transcription or stabilize mRNA. In the absence of iron, IRP2 binds to 5'-end IREs in FPN1 and ferritin to decrease their mRNA stability, and it binds to 3'-end IREs in TFR1 and DMT1 to stabilize mRNA. When there is excess iron in the cells, the synthesis of FPN1 and ferritin mRNA is inhibited and the degradation of TFR1 and DMT1 mRNA is enhanced (Fig. 2) [133].

Additionally, the selenoenzyme glutathione peroxidase 4 (GPX4), which can inhibit the peroxidation of phospholipids (PLs), is considered to be a regulator of ferroptosis, and inactivation of GPX4 will lead to an increase in lipid peroxides. In addition, the accumulation of iron produces lipid peroxides in a nonenzymatic or enzymedependent manner [134]. The nonenzymatic reaction of iron to produce lipid peroxides is the Fenton reaction, $\mathrm{Fe}^{2+}+\mathrm{H}_{2} \mathrm{O}_{2} \rightarrow \mathrm{Fe}^{3+}+(\mathrm{OH})^{-}+\mathrm{OH} \cdot[135,136]$ (Fig. 3). Another pathway for ferroptosis is mediated by the $\mathrm{X}_{\mathrm{c}}{ }^{-}$ system, formed by SLC3A2 and SLC7A11, which internalizes cystine cells and expels glutamic acid, and then cystine is reduced to cysteine. Cysteine participates in the synthesis of GSH. GSH acts as an electron donor to maintain the activity of GPX4, thereby preventing ferroptosis.

\section{Relationship between ferroptosis and CSCs}

The changes in iron homeostasis in CSCs are usually manifested by high intracellular iron content. In addition, abnormal iron metabolism is associated with accelerated tumor growth and a poor prognosis for cancer patients. Therefore, because of the dependence of cancer on iron, iron-dependent mechanisms such as ferroptosis can be used as targets for drug development [137]. A higher level of iron in a CSC may affect its redox state, which is manifested by the increase in peroxidation and $\mathrm{OH} \cdot[138,139]$.

Recently, it was reported that the levels of TfR1 and its ligand transferrin expressed by glioblastoma stem cells are higher than those expressed by non-CSCs, and iron-tracking experiments using these CSCs have shown that the level of iron intake by CSCs is greater than that 


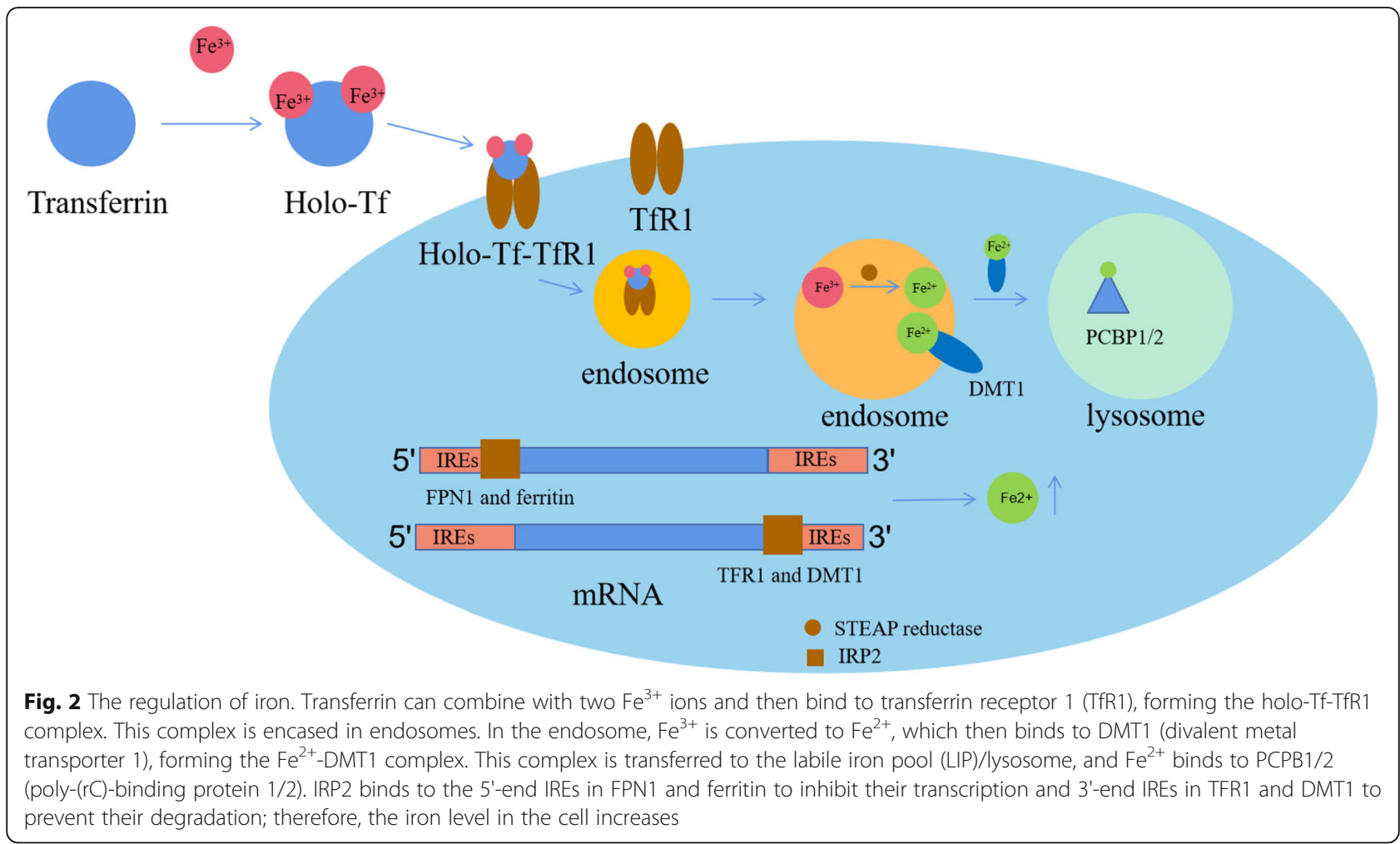

internalized by non-CSCs [140], indicating that increased iron intake may also be a characteristic of CSCs. Additionally, ferritin is overexpressed in a variety of cancers, including breast cancer, pancreatic cancer, liver cancer, Hodgkin's lymphoma, and glioblastoma. Ferritin may protect CSCs, but the degradation of ferritin produces a source of iron leading to ferroptosis. Targeting the $\mathrm{H}$ and $\mathrm{L}$ subunits of ferritin with siRNA causes a significant reduction in the growth of CSCs in vivo and in vitro [140].

\section{Ferroptosis and small-molecule compounds}

Current studies on the activators of ferroptosis are relatively extensive, but there are few small-molecule compounds that can target CSCs by mediating ferroptosis (Fig. 4). Additionally, the role of GPX4 in ferroptosis is decisive. Some experiments have already confirmed that the dysfunction of GPX4 causes mesenchymal stem cell ferroptosis; therefore, small-molecule compounds targeting GPX4 may induce ferroptosis in CSCs, although experimental proof is currently lacking.

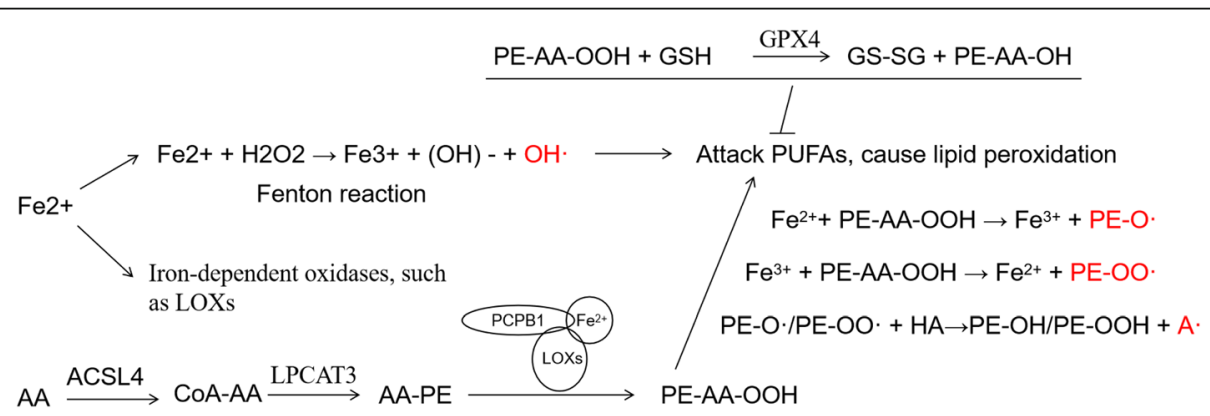

Fig. 3 The role of iron in lipid peroxidation. Through the Fenton reaction, $\mathrm{Fe}^{2+}$ and hydrogen peroxide produces $\mathrm{OH}$, and $\mathrm{AA}$ (arachidonic acid) can produce PE-AA-OOH through ACSL4 (acyl-COA synthetase long-chain family member 4), LPCAT3 (lysophosphatidylcholine acyltransferase 3), and the complex of PCPB1, $\mathrm{Fe}^{2+}$, and LOXs (lipoxygenases). PE-AA-OOH, through $\mathrm{Fe}^{2+}+\mathrm{PE}-\mathrm{AA}-\mathrm{OOH} \rightarrow \mathrm{Fe}^{3+}+\mathrm{PE}-\mathrm{O}, \mathrm{Fe}^{3+}+\mathrm{PE}-\mathrm{AA}-\mathrm{OOH} \rightarrow \mathrm{Fe}{ }^{2+}$ $+\mathrm{PE}-\mathrm{OO}$, and $\mathrm{PE}-\mathrm{O} / \mathrm{PE}-\mathrm{OO}+\mathrm{HA} \rightarrow \mathrm{PE}-\mathrm{OH} / \mathrm{PE}-\mathrm{OOH}+\mathrm{A}$ produces PE-O, PE-OO, and A. OH, PE-O, PE-OO, and A can attack PUFAs (polyunsaturated fatty acids) to cause lipid peroxidation. In addition, GPX4 can inhibit the production of lipid peroxidation through PE-AA-OOH + GSH $\rightarrow$ GS-SG + PE-AA-OH 


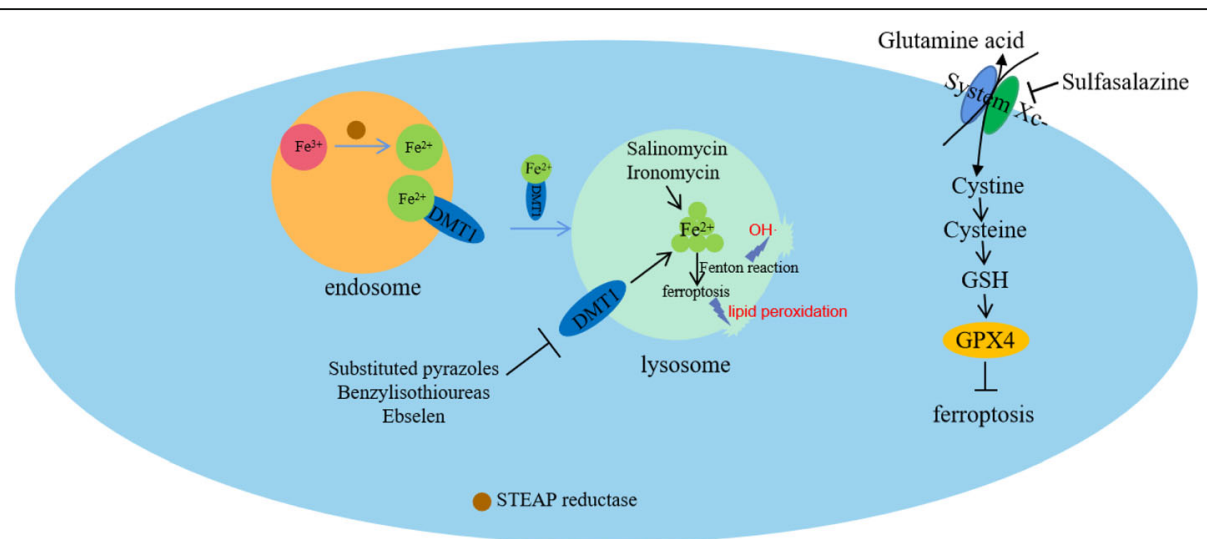

Fig. 4 Summary of small-molecule compounds targeting ferroptosis to induce CSC death. Substituted pyrazoles, benzyl isothioureas, and ebselen can target DMT1 to block iron in lysosomes. Salinomycin and ironomycin can accumulate and isolate iron in the lysosome. Iron in lysosomes can produce $\mathrm{OH}$ through the Fenton reaction, and lipid peroxidation is also undertaken in the ferroptosis process. All the products can lead to increased permeability in the lysosomal membrane and cell death. Sulfasalazine can inhibit System Xc ${ }^{-}$. All these compounds can induce ferroptosis and thus kill CSCS

The following is a summary of some ferroptosis inducers. Erastin, sulfasalazine, and sorafenib can reduce the level of cystine by inhibiting the $\mathrm{X}_{\mathrm{c}}{ }^{-}$system. Sulfasalazine can also inhibit the $\mathrm{X}_{\mathrm{c}}{ }^{-}$system, thereby inhibiting the progression of CSCs overexpression of CD44 in gastrointestinal cancer [141]. (1S, 3R)-RSL3, altretamine and withaferin A can increase lipid peroxidation by inhibiting or silencing GPX4 function [142]. Notably, salinomycin can increase the production of lipid peroxidation by blocking iron transport and depleting ferritin, by which it can specifically kill CSCs [143]. Other studies indicate that a combination of salinomycin and docetaxel can effectively kill gastric CSCs [144]. Salinomycin can effectively destroy non-CSCs and CSCs, as well as cancer cells with a multi-drug resistance (MDR) phenotype; therefore, it shows strong antitumor activity against a variety of cancers [145]. Additionally, salinomycinloaded gold nanoparticles show enhanced ability to target BCSCs [146]. Considering the effect of salinomycin in killing CSCs, many salinomycin derivatives have also been developed and exhibit higher activity and selectivity, such as ironomycin and the products of $\mathrm{C} 20$ amination, C1-esterification, C9-oxidation, and C28dehydration. These derivatives of salinomycin can accumulate and isolate iron in the lysosome, and the accumulation of iron in the lysosome initiates the Fenton reaction, leading to increased permeability in the lysosomal membrane and cell death. They have been shown to be at least ten-fold more potent than salinomycin in vivo and in vitro. In addition, ironomycin can effectively reduce the number of CSCs in docetaxel-resistant xenograft models [143, 147]. Furthermore, ebselen, substituting pyrazole, and benzyl isothiourea, which are the inhibitors of DMT1, can selectively target BCSCs by blocking iron in lysosomes [148]. These results indicate that increasing iron levels in lysosomes can initiate cell death in a manner similar to ferroptosis, and thus specifically and effectively kill CSCs. However, the concrete mechanisms by which the drugs target DMT1 are still unclear.

Notably, recent studies have shown that ovarian CSCs rely on iron for self-renewal and metastasis [149]. This finding reveals an opportunity to treat cancer by regulating iron balance. For example, after treatment with erastin, CSCs are more likely to induce ferroptosis than are non-CSCs [149]. The combination of temozolomide (TMZ) and CQ can cause glioblastoma stem cells (GSCs) to die in the form of ferroptosis, and specifically, this combination can reduce the self-renewal of GSCs, weaken the invasion of glioblastoma, and improve the therapeutic efficiency of chemotherapy and radiotherapy, but the specific target has not been identified [150].

Recently, an increasing number of studies have shown that artemisinin derivatives have anticancer ability. For example, dihydroartemisinin (DHA) can increase iron levels in the cell and inhibit the synthesis of ferritin through the IRP-IRE axis, which increases the concentration of intracellular iron, making cancer cells (such as lung, colorectal, and breast cancer cells) more sensitive to ferroptosis [151]. In addition, it was found that DHA can inhibit sphere formation and stem marker (CD133, SOX2, and nestin) expression in glioma CSCs [152]. Therefore, DHA may inhibit CSCs through ferroptosis. Through a platform of induced cancer stem-like cells (iCSCLs) used for high-throughput screening, artesunate can induce mitochondrial dysfunction in CSCs; therefore, it can inhibit the stemness of CSCs [153]. Artesunate can induce ferroptosis in pancreatic cancer [154]. All these findings indicate that artemisinin derivatives may target CSCs through ferroptosis. Ferumoxytol is a 
superparamagnetic iron oxide nanoparticle approved by the FDA, and its anticancer ability is associated with ferroptosis [155]. Magnetic hyperthermia is a new method by which to selectively kill CSCs (A549 and MDA-MB231), and the key aspect of this technology is superparamagnetic iron oxide nanoparticles [156]. The report indicated that ferumoxytol was a new material for use in magnetic hyperthermia [157]. In addition, DOX@FMT$\mathrm{MC}$, a novel magnetic hydrogel complex consisting of ferumoxytol, doxorubicin, and chitosan, was applied in the clinic to treat colon carcinoma [158]. Therefore, ferumoxytol may target CSCs by ferroptosis (Table 6).

According to the current research, the relationship between ferroptosis and CSCs has received increasing attention. In contrast, there are few reports of GPX4 in CSCs. Therefore, to some extent, the role of iron in CSCs is seemingly more dependent on GPX4 dysfunction, which causes normal stem cells to die in an irondependent manner $[171,172]$.

\section{Multiple-signaling pathway inhibitors targeting CSCs}

As we stated above, there are many signaling pathways regulating CSC progression. Hence, the compounds that simultaneously target multiple signaling pathways critical for CSC progression may yield better results than single-target treatments in controlling tumor occurrence, recurrence, and drug resistance (Table 7). For example, Z-ajoene, a compound extracted from garlic, was confirmed to inhibit CSC sphere-forming ability in glioblastoma multiforme (GBM), and Notch-, Wnt-, and Hh-related genes ware changed after treatment with Zajoene. In addition, Z-ajoene induced no cytotoxicity in normal cells [173]. Poziotinib, a pan-human epidermal growth factor receptor (HER) inhibitor, can decrease ovarian CSC sphere formation ability by disrupting the Wnt, Notch, and Hh signaling pathways in epithelial ovarian cancer (EOC) [176]. According to clinical studies, patients may experience diarrhea and rash when treated with poziotinib [174]. However, considering the multiple targets and anti-CSC activity of poziotinib, more studies are needed in the future. Additionally, 6shogaol reduces the number of $\mathrm{CD} 44^{+} / \mathrm{CD} 24^{-}$cell subpopulation in BCSCs and inhibit their sphere-forming ability by inducing autophagy and inhibiting the Notch signaling pathway [177]. Importantly, 6-shogaol shows low toxicity induction in normal cells [175].

\section{Conclusions}

This review summarizes several well-characterized signaling pathways involved in CSCs, such as Wnt, Hh, Notch, Hippo, autophagy, and ferroptosis, and focuses on small-molecule compounds regulating these pathways (Fig. 5). Finally, these small-molecule compounds have the potential to kill CSCs, which provides a basis for cancer treatment. It is noteworthy that there are many other pathways, such as PI3K/Akt, MAPK, JAK/ Stat, and TGF- $\beta$ [178], essential for CSC survival, but these pathways are also widely engaged in other biological processes, and targeting them would not be specific to CSCs; however, the Wnt, Hh, Notch, and Hippo pathways are the mainstream pathways in CSCs, which have already been well studied. Therefore, in this current review, we summarize the small-molecule compounds targeting the Wnt, Hh, Notch, and Hippo pathways to kill CSCs. Although targeting ferroptosis to kill CSCs has recently been invoked, the effects have been strongly established by many studies [143, 147, 148]. Recently, although biologics have been rapidly developed, smallmolecule compounds are still needed for clinical application.

Compared with biologics (such as monoclonal antibodies and antibody-drug conjugates), small-molecule compounds are inexpensive, and the generic drugs made from them are relatively simple, which means that small-molecule compounds may have the potential to compete with biologics. In addition, we present an overall assessment of these small-molecule compounds in Tables 1, 2, 3, 4, 5, and 6. Most chemotherapy drugs induce toxicity to different degrees. Therefore, we need to find a balance between anticancer effects and side effects of compounds used to target CSCs. The process from drug development to clinical use is long. Although approved drugs always induce specific toxicities, they have been well studied, and drug repurposing may offer a shortcut to prevent financial loss and detoured efforts. Therefore, in this review, we list many drugs approved by FDA, such as Wnt inhibitors (niclosamide, TFP, DTX and SFN, PP, AD and Ts); Notch inhibitors (DAPT); Hh inhibitor (glasdegib, sonidegib, vismodegib, ciclesonide); Hippo inhibitors (verteporfin, fluvastatin, atorvastatin, $\mathrm{CPZ})$; autophagy regulators $(\mathrm{CQ}, \mathrm{HCQ}$, pantoprazole); ferroptosis inducers (TMZ and CQ, artesunate, ferumoxytol, sulfasalazine). These drugs display anti-CSC abilities, and some have been entered into clinical studies. In particular, an Hh inhibitor (glasdegib) has been approved by the FDA for its efficient anti-CSC action, which is similar to that of the biologics ELZONRIS. In addition, there are many new small-molecule compounds that are well tolerated, according to the current studies, but conclusive outcomes still need to be proven by more studies, and the toxicities of the following compounds have not been reported, which may be the result of insufficient experiments: Wnt inhibitors (ONC201, TFP, chelerythrine, FH535, Wnt-C59, IWR-1, IC-2, JIB04, PP, OXT-328, OXT-328), Notch inhibitors (MK0752, DAPT), Hh inhibitors (ciclesonide, GANT61), Hippo inhibitors (verteporfin, evodiamine, fluvastatin, 


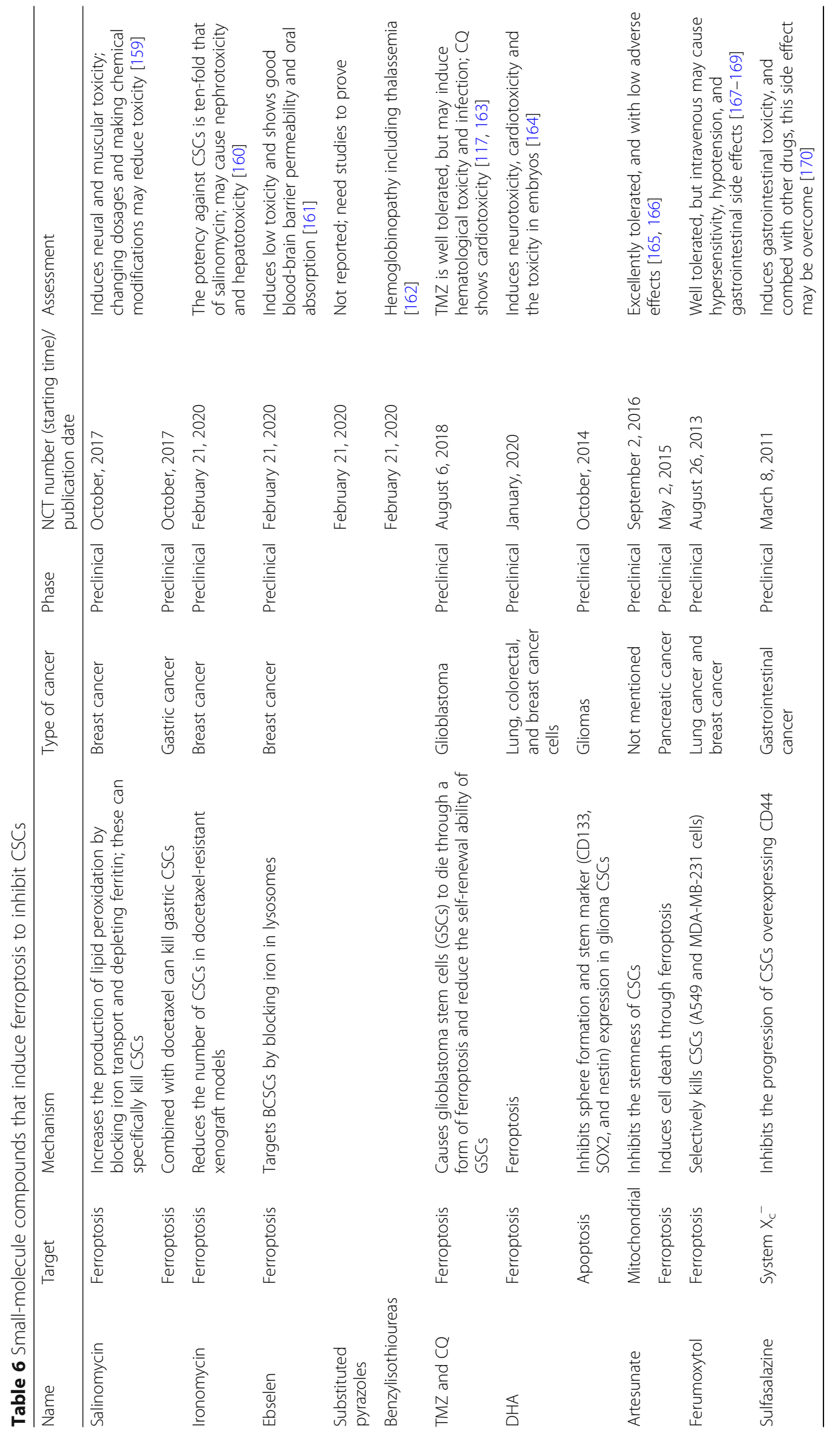


Table 7 Small-molecule compounds regulating multi-signaling pathways to inhibit CSCs

\begin{tabular}{|c|c|c|c|c|c|c|}
\hline Name & Target & Mechanism & $\begin{array}{l}\text { Type of } \\
\text { cancer }\end{array}$ & Phase & $\begin{array}{l}\text { NCT number (starting } \\
\text { time)/publication date }\end{array}$ & Assessment \\
\hline Z-ajoene & $\begin{array}{l}\text { Notch, Wnt, } \\
\text { and Hh }\end{array}$ & Inhibits CSC sphere-forming ability & $\begin{array}{l}\text { Glioblastoma } \\
\text { multiforme }\end{array}$ & Preclinical & July, 2014 & $\begin{array}{l}\text { Without cytotoxic in } \\
\text { normal cells [173] }\end{array}$ \\
\hline Poziotinib & $\begin{array}{l}\text { Wnt, Notch, } \\
\text { and Hh }\end{array}$ & Decreases ovarian CSC sphere formation ability & $\begin{array}{l}\text { Epithelial } \\
\text { ovarian } \\
\text { cancer }\end{array}$ & Preclinical & May 21, 2020 & $\begin{array}{l}\text { Diarrhea and rash } \\
{[174]}\end{array}$ \\
\hline $\begin{array}{l}\text { 6- } \\
\text { Shogaol }\end{array}$ & $\begin{array}{l}\text { Notch and } \\
\text { autophagy }\end{array}$ & $\begin{array}{l}\text { Inhibits the number of CD } 44+/ C D 24-\text { cell } \\
\text { subpopulation and decreases sphere-forming } \\
\text { ability }\end{array}$ & Breast cancer & Preclinical & September 10, 2015 & $\begin{array}{l}\text { Induces low toxicity } \\
\text { in normal cells [175] }\end{array}$ \\
\hline
\end{tabular}

CA3), autophagy regulators (3-MA, Rott), ferroptosis inducers (ebselen, substituted pyrazoles, TMZ, CQ, Artesunate, Ferumoxytol). Furthermore, we also listed some new CSC-targeting compounds that are in the preclinical or phase I/II stage: Wnt inhibitors (Wnt974, XAV939), Notch inhibitors (PF-03084014, RO4929097, quinomycin A), Hh inhibitor (cyclopamine), ferroptosis inducers (salinomycin, ironomycin, benzylisothioureas). These compounds also show antiCSC activities, and the toxicities they induce may be reduced by changing the dosage, and developing new derivatives and combination therapies. To our surprise, some compounds are DLTs, especially the Notch inhibitors, and because of their side effect, additional research is needed to determine precise effective and safe dosage. In summary, according to the current studies, the compounds targeting CSCs are well tolerated in the mice or patients, and the compounds targeting multi-oncogenic signaling pathways may play important role in the clinic studies.

There are more detailed studies supporting the use of small-molecule compounds targeting Wnt, Hh, Notch, Hippo, and autophagy to inhibit CSCs, and many compounds are currently in clinical research. Although many small-molecule compounds activate ferroptosis, these studies have been conducted at the cell and mouse levels, and no clinical studies have been reported. However, based on the specificity and strong inhibitory ability of salinomycin and ironomycin and their derivatives on CSCs, these small-molecule compounds may have strong potential as target CSCs, and ferroptosis induced by iron in lysosomes may be a valuable prospect as a clinical target in CSCs to promote the development of anticancer drugs. However, it is noteworthy that there are different pathways in CSCs abnormally expressed; therefore, monotherapies that can target different

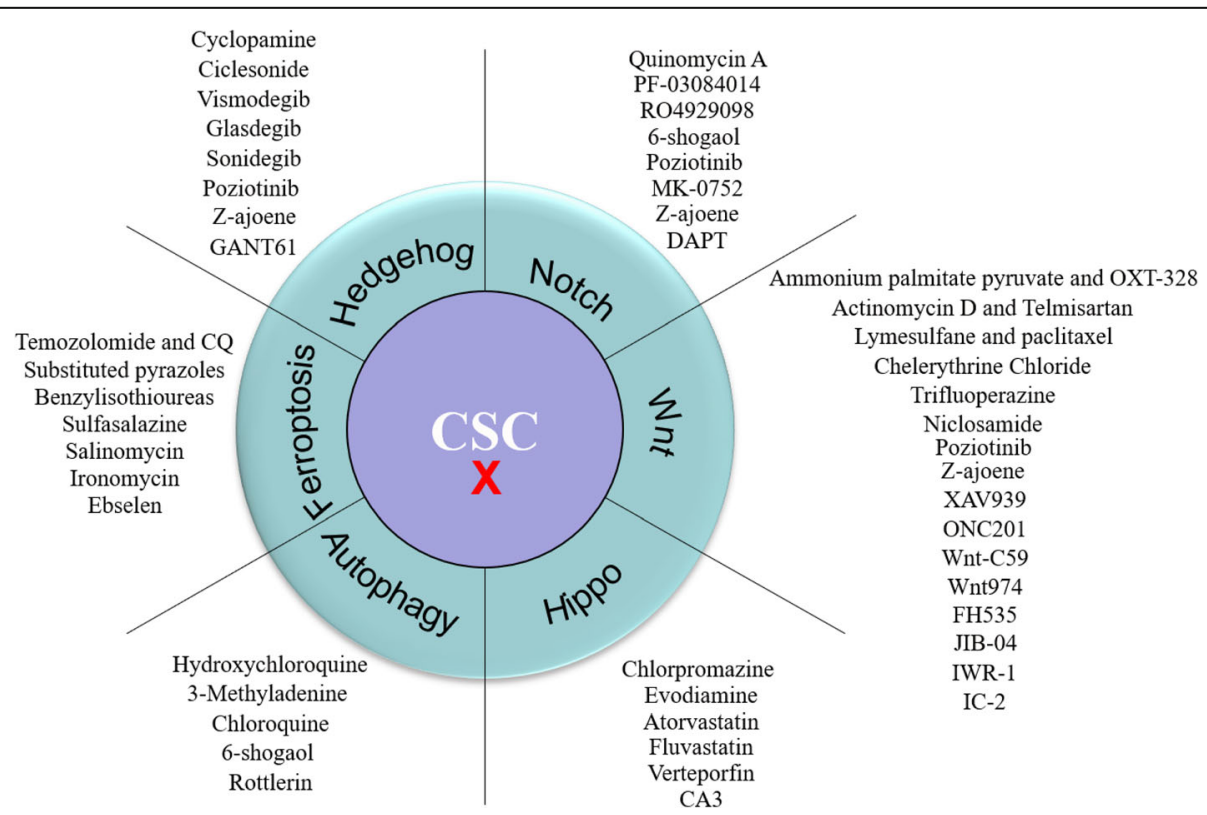

Fig. 5 Summary of small-molecule compounds targeting CSCs. This figure lists all small-molecule compounds in this review targeting CSCS through different pathways 
pathways simultaneously or combined therapies may yield the best results in the future. Importantly, to our knowledge, targeting CSCs alone is sufficient for cancer therapy in the early stage of tumorigenesis, but it is not sufficient in the tumor development period, as many small-molecule compounds targeting CSCs cannot kill cancer cells, and the combined use of drugs targeting CSCs and chemotherapeutics may lead to better effects during tumor development period.

\begin{abstract}
Abbreviations
CSCs: Cancer stem cells; Hh: Hedgehog; LRP: Lipoprotein receptor-related protein; TNBC: Triple negative breast cancer; TBD: Terminal anchor polymerase binding domain; HNSCC: Neck squamous cell carcinoma; CRC: Colorectal cancer; TFP: Trifluoperazine; NSCLC: Non-small cell lung carcinoma; NPC: Nasopharyngeal carcinoma; HCC: Hepatocellular carcinoma; DTX: Docetaxel; SFN: Sulforaphane; PP: Pyrvinium pamoate; EMT: Epithelialmesenchymal transition; AD: Actinomycin D; TS: Telmisartan; DLL: Delta-like ligand; NICD: Notch intracellular domain; DLT: Dose-limiting toxicity; INS: Insulinomas; LSCs: Leukemia stem cells; SMO: Smoothened; ER: Estrogen receptor; BCSC: Breast cancer stem cell; TEAD: TEA domain family members; Evo: Evodiamine; CPZ: Chlorpromazine; CQ: Chloroquine; HCQ: Hydroxychloroquine; IM: Imatinib; mCRPC: Metastatic castrationresistant prostate cancer; PPI: Proton pump inhibitor; 3-MA: 3-Methyladenine: Rott: Rottlerin; ROS: Reactive oxygen species; TfR1: Transferrin receptor 1; DMT1: Divalent metal transporter 1; LIP: Labile iron pool; PCBP1/2: Poly (rC)binding protein 1/2; IRP2: Iron regulatory proteins 2; IREs: Iron-responsive elements; UTRs: Untranslated regions; Gpx4: Glutathione peroxidase 4; PLs: Phospholipids; PUFAs: Polyunsaturated fatty acids; LOXs: Lipoxygenases; AA: Arachidonic acid; ACSL4: Acyl-CoA synthetase long-chain family member; LPCAT3: Lysophosphatidylcholine acyltransferase 3; MDR: Multi-drug resistance; TMZ: Temozolomide; GSCs: Glioblastoma stem cells; DHA: Dihydroartemisinin; iCSCL: Induced cancer stem-like cells; GBM: Glioblastoma multiforme; HER: Pan-human epidermal growth factor receptor; EOC: Epithelial ovarian cancer
\end{abstract}

\section{Acknowledgements}

Not applicable

\section{Authors' contributions}

Yue Yang, Lufeng Zheng, Xiaoman Li, Ting Wang, and Qianqian Guo wrote this paper. Tao Xi and Lufeng Zheng reviewed this paper. All authors read and approved the final manuscript.

\section{Funding}

This work was supported by the National Natural Science Foundation of China, No. 81903857, 81702957; the Special Postdoctoral Funding Scheme of China, No. 2019T120485; the Postdoctoral Science Foundation of China, No. 2017M620230; the Basic Scientific Research Business Expense Project of China Pharmaceutical University, No. 2632020ZD10; the Science and Technology Research Project of Henan Province, No. 202102310158; and the Priority Academic Program Development (PAPD) of Jiangsu Higher Education Institutions.

\section{Availability of data and materials}

Not applicable

\section{Ethics approval and consent to participate}

Not applicable

\section{Consent for publication}

Not applicable

\section{Competing interests}

The authors declare that they have no competing interests.

\section{Author details}

'School of Life Science and Technology, Jiangsu Key Laboratory of

Carcinogenesis and Intervention, China Pharmaceutical University, 639
Longmian Road, Nanjing 211198, People's Republic of China. ${ }^{2}$ Jiangsu Key Laboratory for Pharmacology and Safety Evaluation of Chinese Materia Medica, School of Pharmacy, Nanjing University of Chinese Medicine, Nanjing 210023, People's Republic of China. ${ }^{3}$ Department of Pharmacy, Affiliated Cancer Hospital of Zhengzhou University, Henan Cancer Hospital, 127 Dongming Road, Zhengzhou 450003, People's Republic of China.

Received: 15 March 2020 Accepted: 18 May 2020

Published online: 26 May 2020

\section{References}

1. Chang JC. Cancer stem cells: role in tumor growth, recurrence, metastasis, and treatment resistance. Medicine. 2016;95(1S Suppl 1):S20-5.

2. Zhu Q, Shen Y, Chen X, He J, Liu J, Zu X. Self-renewal signalling pathway inhibitors: perspectives on therapeutic approaches for cancer stem cells. OncoTargets and therapy. 2020;13:525-40.

3. Nassar D, Blanpain C. Cancer stem cells: basic concepts and therapeutic implications. Annu Rev Pathol. 2016;11:47-76.

4. Katoh M. Canonical and non-canonical WNT signaling in cancer stem cells and their niches: cellular heterogeneity, omics reprogramming, targeted therapy and tumor plasticity (Review). Int J Oncol. 2017;51(5):1357-69.

5. Reya T, Morrison SJ, Clarke MF, Weissman IL. Stem cells, cancer, and cancer stem cells. Nature. 2001;414(6859):105.

6. Kreso A, Dick JE. Evolution of the cancer stem cell model. Cell Stem Cell. 2014;14(3):275-91.

7. An SM, Ding Q, Zhang J, Xie J, Li L. Targeting stem cell signaling pathways for drug discovery: advances in the Notch and Wnt pathways. Sci China Life Sci. 2014;57(6):575-80.

8. Takebe N, Miele L, Harris PJ, Jeong W, Bando H, Kahn M, Yang SX, Ivy SP. Targeting Notch, Hedgehog, and Wnt pathways in cancer stem cells: clinical update. Nat Rev Clin Oncol. 2015;12(8):445-64.

9. Bouvard C, Barefield C, Zhu S. Cancer stem cells as a target population for drug discovery. Future Med Chem. 2014;6(14):1567-85.

10. Takebe N, Harris PJ, Warren RQ, Ivy SP. Targeting cancer stem cells by inhibiting Wnt, Notch, and Hedgehog pathways. Nat Rev Clin Oncol. 2011; 8(2):97-106

11. Solzak JP, Atale RV, Hancock BA, Sinn AL, Pollok KE, Jones DR, Radovich M. Dual PI3K and Wnt pathway inhibition is a synergistic combination against triple negative breast cancer. NPJ breast cancer. 2017;3:17.

12. Burock S, Daum S, Keilholz U, Neumann K, Walther W, Stein U. Phase II trial to investigate the safety and efficacy of orally applied niclosamide in patients with metachronous or sychronous metastases of a colorectal cancer progressing after therapy: the NIKOLO trial. BMC Cancer. 2018;18(1): 297.

13. Lin CK, Bai MY, Hu TM, Wang YC, Chao TK, Weng SJ, Huang RL, Su PH, Lai HC. Preclinical evaluation of a nanoformulated antihelminthic, niclosamide, in ovarian cancer. Oncotarget. 2016;7(8):8993-9006.

14. Ye T, Xiong Y, Yan Y, Xia Y, Song X, Liu L, Li D, Wang N, Zhang L, Zhu Y, et al. The anthelmintic drug niclosamide induces apoptosis, impairs metastasis and reduces immunosuppressive cells in breast cancer model. PLoS One. 2014;9(1):e85887.

15. Arrillaga-Romany I, Chi AS, Allen JE, Oster W, Wen PY, Batchelor TT. A phase 2 study of the first imipridone ONC201, a selective DRD2 antagonist for oncology, administered every three weeks in recurrent glioblastoma. Oncotarget. 2017:8(45):79298-304.

16. Arrillaga-Romany I, Odia Y, Prabhu W, Tarapore RS, Merdinger K, Stogniew M, Oster W, Allen JE, Mehta M, Batchelor TT, et al. Biological activity of weekly ONC201 in adult recurrent glioblastoma patients. Neuro-oncology. 2020;22(1):94-102

17. Liu M, Tu J, Gingold JA, Kong CSL, Lee DF. Cancer in a dish: progress using stem cells as a platform for cancer research. Am J Cancer Res. 2018;8(6): 944-54.

18. Budd GT, Bukowski RM, Lichtin A, Bauer L, Van Kirk P, Ganapathi R. Phase II trial of doxorubicin and trifluoperazine in metastatic breast cancer. Invest New Drugs. 1993;11(1):75-9.

19. Li J, Yao QY, Xue JS, Wang LJ, Yuan Y, Tian XY, Su H, Wang SY, Chen WJ, Lu $W$, et al. Dopamine D2 receptor antagonist sulpiride enhances dexamethasone responses in the treatment of drug-resistant and metastatic breast cancer. Acta Pharmacol Sin. 2017;38(9):1282-96.

20. Chmura SJ, Dolan ME, Cha A, Mauceri HJ, Kufe DW, Weichselbaum RR. In vitro and in vivo activity of protein kinase $\mathrm{C}$ inhibitor chelerythrine chloride 
induces tumor cell toxicity and growth delay in vivo. Clin Cancer Res. 2000; 6(2):737-42.

21. Medvetz D, Sun Y, Li C, Khabibullin D, Balan M, Parkhitko A, Priolo C, Asara JM, Pal S, Yu J, et al. High-throughput drug screen identifies chelerythrine as a selective inducer of death in a TSC2-null setting. Mol Cancer Res. 2015; 13(1):50-62.

22. Razak S, Afsar T, Almajwal A, Alam I, Jahan S. Growth inhibition and apoptosis in colorectal cancer cells induced by vitamin D-nanoemulsion (NVD): involvement of Wnt/beta-catenin and other signal transduction pathways. Cell Biosci. 2019;9:15.

23. Proffitt KD, Madan B, Ke Z, Pendharkar V, Ding L, Lee MA, Hannoush RN, Virshup DM. Pharmacological inhibition of the Wnt acyltransferase PORCN prevents growth of WNT-driven mammary cancer. Cancer Res. 2013;73(2):502-7.

24. Martins-Neves SR, Paiva-Oliveira DI, Fontes-Ribeiro C, Bovee J, Cleton-Jansen AM, Gomes CMF. IWR-1, a tankyrase inhibitor, attenuates Wnt/beta-catenin signaling in cancer stem-like cells and inhibits in vivo the growth of a subcutaneous human osteosarcoma xenograft. Cancer Lett. 2018;414:1-15.

25. Wang L, Chang J, Varghese D, Dellinger M, Kumar S, Best AM, Ruiz J, Bruick R, PenaLlopis S, Xu J, et al. A small molecule modulates Jumonji histone demethylase activity and selectively inhibits cancer growth. Nat Commun. 2013;4:2035.

26. Kamal MM, Nazzal S. Development of a new class of sulforaphane-enabled self-emulsifying drug delivery systems (SFN-SEDDS) by high throughput screening: a case study with curcumin. Int J Pharm. 2018;539(1-2):147-56.

27. Kenmotsu H, Tanigawara Y. Pharmacokinetics, dynamics and toxicity of docetaxel: why the Japanese dose differs from the Western dose. Cancer Sci. 2015;106(5):497-504.

28. Xu W, Lacerda L, Debeb BG, Atkinson RL, Solley TN, Li L, Orton D, McMurray $J \mathrm{~S}$, Hang $\mathrm{Bl}$, Lee $\mathrm{E}$, et al. The antihelmintic drug pyrvinium pamoate targets aggressive breast cancer. PLoS One. 2013;8(8):e71508.

29. Koyama N, Nishida Y, Ishii T, Yoshida T, Furukawa Y, Narahara H. Telmisartan induces growth inhibition, DNA double-strand breaks and apoptosis in human endometrial cancer cells. PLoS One. 2014:9(3):e93050.

30. Lamture G, Crooks PA, Borrelli MJ. Actinomycin-D and dimethylaminoparthenolide synergism in treating human pancreatic cancer cells. Drug Dev Res. 2018;79(6):287-94.

31. de Sousa EMF, Vermeulen L. Wnt signaling in cancer stem cell biology. Cancers. 2016:8(7).

32. Curtin JC, Lorenzi MV. Erratum: drug discovery approaches to target Wnt signaling in cancer stem cells. Oncotarget. 2018;9(78):34856.

33. Takahashi-Yanaga F, Kahn M. Targeting Wnt signaling: can we safely eradicate cancer stem cells? Clin cancer res. 2010;16(12):3153-62.

34. Takada R, Satomi Y, Kurata T, Ueno N, Norioka S, Kondoh H, Takao T, Takada S. Monounsaturated fatty acid modification of Wnt protein: its role in Wnt secretion. Dev Cell. 2006;11(6):791-801.

35. Zhao Z, Lu P, Zhang H, Xu H, Gao N. Nestin positively regulates the Wnt/Bcatenin pathway and the proliferation, survival and invasiveness of breast cancer stem cells. Breast Cancer Res. 2014;16(4):408.

36. Arend RC, Londono-Joshi Al, Samant RS, Li Y, Conner M, Hidalgo B, Alvarez RD, Landen CN, Straughn JM, Buchsbaum DJ. Inhibition of Wnt/beta-catenin pathway by niclosamide: a therapeutic target for ovarian cancer. Gynecol Oncol. 2014;134(1):112-20.

37. Londono-Joshi Al, Arend RC, Aristizabal L, Lu W, Samant RS, Metge BJ, Hidalgo B, Grizzle WE, Conner M, Forero-Torres A, et al. Effect of niclosamide on basal-like breast cancers. Mol Cancer Ther. 2014;13(4):800-11.

38. Park SY, Kim JY, Choi JH, Kim JH, Lee CJ, Singh P, Sarkar S, Baek JH, Nam JS. Inhibition of LEF1-mediated DCLK1 by niclosamide attenuates colorectal cancer stemness. Clin Cancer Res. 2019;25(4):1415-29.

39. Prabhu W, Lulla AR, Madhukar NS, Ralff MD, El-Deiry WS. Cancer stem cellrelated gene expression as a potential biomarker of response for first-inclass imipridone ONC201 in solid tumors. Plos One. 2017;12(8):e0180541.

40. Huang SMA, Mishina YM, Liu S, Cheung A, Stegmeier F, Michaud GA, Charlat O, Wiellette E, Zhang Y, Wiessner S. Tankyrase inhibition stabilizes axin and antagonizes Wnt signalling. Nature. 2009:461(7264):614-20.

41. Roy S, Roy S, Kar M, Chakraborty A, Kumar A, Delogu F, Asthana S, Hande MP, Banerjee B. Combined treatment with cisplatin and the tankyrase inhibitor XAV-939 increases cytotoxicity, abrogates cancer-stem-like cell phenotype and increases chemosensitivity of head-and-neck squamous-cell carcinoma cells. Mutat Res. 2019:846:503084.

42. Wu X, Luo F, Li J, Zhong X, Liu K. Tankyrase 1 inhibitior XAV939 increases chemosensitivity in colon cancer cell lines via inhibition of the Wnt signaling pathway. Int J Oncol. 2016;48(4):1333-40.
43. Yeh CT, Wu AT, Chang PM, Chen KY, Yang CN, Yang SC, Ho CC, Chen CC, Kuo YL, Lee PY, et al. Trifluoperazine, an antipsychotic agent, inhibits cancer stem cell growth and overcomes drug resistance of lung cancer. Am J Respir Crit Care Med. 2012;186(11):1180-8.

44. Heng WS, Cheah SC. Chelerythrine chloride downregulates beta-catenin and inhibits stem cell properties of non-small cell lung carcinoma. Molecules. 2020;25(1):224.

45. Liu L, Zhi Q, Shen M, Gong FR, Zhou BP, Lian L, Shen B, Chen K, Duan W, Wu MY, et al. FH535, a beta-catenin pathway inhibitor, represses pancreatic cancer xenograft growth and angiogenesis. Oncotarget. 2016;7(30):4714562.

46. Cheng Y, Phoon YP, Jin X, Chong SY, Ip JC, Wong BW, Lung ML. Wnt-C59 arrests stemness and suppresses growth of nasopharyngeal carcinoma in mice by inhibiting the Wnt pathway in the tumor microenvironment. Oncotarget. 2015;6(16):14428-39.

47. Seto K, Sakabe T, Itaba N, Azumi J, Oka H, Morimoto M, Umekita Y, Shiota G. A novel small-molecule WNT inhibitor, IC-2, has the potential to suppress liver cancer stem cells. Anticancer Res. 2017;37(7):3569-79.

48. Urushibara S, Tsubota T, Asai R, Azumi J, Ashida K, Fujiwara Y, Shiota G. WNT/beta-catenin signaling inhibitor IC-2 suppresses sphere formation and sensitizes colorectal cancer cells to 5-fluorouracil. Anticancer Res. 2017;37(8): 4085-91.

49. Kim MS, Cho HI, Yoon HJ, Ahn YH, Park EJ, Jin YH, Jang YK. JIB-04, a small molecule histone demethylase inhibitor, selectively targets colorectal cancer stem cells by inhibiting the Wnt/beta-catenin signaling pathway. Sci Rep. 2018:8(1):6611.

50. Huang J, Tao C, Yu Y, Yu F, Zhang H, Gao J, Wang D, Chen Y, Gao J, Zhang G. Simultaneous targeting of differentiated breast cancer cells and breast cancer stem cells by combination of docetaxel- and dulforaphane-loaded self-assembled poly(D, L-lactide-co-glycolide)/hyaluronic acid block copolymer-based nanoparticles. J Biomed Nanotechnol. 2016;12(7):1463.

51. Liang XU, Zhang LE, Chun HU, Liang S, Fei X. WNT pathway inhibitor pyrvinium pamoate inhibits the self-renewal and metastasis of breast cancer stem cells. Int J Oncol. 2016;48(3):1175-86.

52. Zhu C, Cheng KW, Ouyang N, Huang L, Sun Y, Constantinides P, Rigas B. Phosphosulindac (OXT-328) selectively targets breast cancer stem cells in vitro and in human breast cancer xenografts. Stem Cells, 75. 2012;30: 2065.

53. Green R, Howell M, Khalil R, Nair R, Yan J, Foran E, Katiri S, Banerjee J, Singh $M$, Bharadwaj $S$, et al. Actinomycin D and telmisartan combination targets lung cancer stem cells through the Wnt/beta catenin pathway. Sci Rep. 2019;9(1):18177.

54. Espinoza I, Miele L. Notch inhibitors for cancer treatment. Pharmacol Ther. 2013;139(2):95-110.

55. Schweisguth F. Regulation of notch signaling activity. Current biology : CB. 2004;14(3):R129-38.

56. Nefedova Y, Sullivan DM, Bolick SC, Dalton WS, Gabrilovich DI. Inhibition of Notch signaling induces apoptosis of myeloma cells and enhances sensitivity to chemotherapy. Blood. 2008;111(4):2220-9.

57. Vandana V, Raghu N, S. TG, Murugesan K, Ashok G, B. KS, Gobianand K, Gowdru KC, M. BK: Targeting Notch signalling pathway of cancer stem cells. Stem Cell Investigation 2018, 5:5-5.

58. Krop I, Demuth T, Guthrie T, Wen PY, Mason WP, Chinnaiyan P, Butowski N, Groves MD, Kesari S, Freedman SJ, et al. Phase I pharmacologic and pharmacodynamic study of the gamma secretase (Notch) inhibitor MK-0752 in adult patients with advanced solid tumors. J Clin Oncol. 2012;30(19): 2307-13.

59. Samon JB, Castillo-Martin M, Hadler M, Ambesi-Impiobato A, Paietta E, Racevskis J, Wiernik PH, Rowe JM, Jakubczak J, Randolph S, et al. Preclinical analysis of the gamma-secretase inhibitor PF-03084014 in combination with glucocorticoids in T-cell acute lymphoblastic leukemia. Mol Cancer Ther. 2012;11(7):1565-75.

60. Tolcher AW, Messersmith WA, Mikulski SM, Papadopoulos KP, Kwak EL, Gibbon DG, Patnaik A, Falchook GS, Dasari A, Shapiro Gl, et al. Phase I study of RO4929097, a gamma secretase inhibitor of Notch signaling, in patients with refractory metastatic or locally advanced solid tumors. J Clin Oncol. 2012;30(19):2348-53

61. Zhou Y, Gregor VE, Sun Z, Ayida BK, Winters GC, Murphy D, Simonsen KB, Vourloumis D, Fish S, Froelich JM, et al. Structure-guided discovery of novel aminoglycoside mimetics as antibacterial translation inhibitors. Antimicrob Agents Chemother. 2005;49(12):4942-9. 
62. Harvey JH, McFadden M, Andrews WG, Byrne PJ, Ahlgren JD, Woolley PV. Phase I study of echinomycin administered on an intermittent bolus schedule. Cancer Treat Rep. 1985;69(12):1365-8.

63. Schott AF, Landis MD, Dontu G, Griffith KA, Layman RM, Krop I, Paskett LA, Wong $H$, Dobrolecki LE, Lewis MT, et al. Preclinical and clinical studies of gamma secretase inhibitors with docetaxel on human breast tumors. Clin Cancer Res. 2013;19(6):1512-24.

64. Wu CX, Xu A, Zhang CC, Olson P, Chen L, Lee TK, Cheung TT, Lo CM, Wang $X Q$. Notch inhibitor PF-03084014 inhibits hepatocellular carcinoma growth and metastasis via suppression of cancer stemness due to reduced activation of Notch1-Stat3. Mol Cancer Ther. 2017;16(8):1531-43.

65. Yabuuchi S, Pai SG, Campbell NR, de Wilde RF, De Oliveira E, Korangath P, Streppel MM, Rasheed ZA, Hidalgo M, Maitra A, et al. Notch signaling pathway targeted therapy suppresses tumor progression and metastatic spread in pancreatic cancer. Cancer Lett. 2013;335(1):41-51.

66. Zhang CC, Yan Z, Zong Q, Fang DD, Painter C, Zhang Q, Chen E, Lira ME, John-Baptiste A, Christensen JG. Synergistic effect of the gamma-secretase inhibitor PF-03084014 and docetaxel in breast cancer models. Stem Cells Transl Med. 2013;2(3):233-42.

67. Chanh H, Laura P, SM F, Ratna M, Adele H, Silvia M, Shulian S, Anna P, Yongzhao S, Farbod D. The novel gamma secretase inhibitor RO4929097 reduces the tumor initiating potential of melanoma. Plos One. 2011;6(9): e25264.

68. Capodanno Y, Buishand FO, Pang LY, Kirpensteijn J, Mol JA, Argyle DJ. Notch pathway inhibition targets chemoresistant insulinoma cancer stem cells. Endocr Relat Cancer. 2018:25(2):131-44.

69. Zhao ZL, Zhang L, Huang CF, Ma SR, Bu LL, Liu JF, Yu GT, Liu B, Gutkind JS, Kulkarni $A B$, et al. NOTCH1 inhibition enhances the efficacy of conventional chemotherapeutic agents by targeting head neck cancer stem cell. Sci Rep. 2016;6:24704.

70. Gal H, Amariglio N, Trakhtenbrot L, Jacob-Hirsh J, Margalit O, Avigdor A, Nagler A, Tavor S, Ein-Dor L, Lapidot T, et al. Gene expression profiles of $\mathrm{AML}$ derived stem cells; similarity to hematopoietic stem cells. Leukemia. 2006;20(12):2147-54

71. Jiang LY, Zhang XL, Du P, Zheng JH. gamma-Secretase inhibitor, DAPT inhibits self-renewal and stemness maintenance of ovarian cancer stem-like cells in vitro. Chinese journal of cancer research $=$ Chung-kuo yen cheng yen chiu. 2011:23(2):140-6.

72. Ponnurangam S, Dandawate PR, Dhar A, Tawfik OW, Parab RR, Mishra PD, Ranadive P, Sharma R, Mahajan G, Umar S, et al. Quinomycin A targets Notch signaling pathway in pancreatic cancer stem cells. Oncotarget. 2016; 7(3):3217-32.

73. Norsworthy KJ, By K, Subramaniam S, Zhuang L, Del Valle PL, Przepiorka D, Shen YL, Sheth CM, Liu C, Leong R, et al. FDA approval summary: glasdegib for newly diagnosed acute myeloid leukemia. Clin Cancer Res. 2019;25(20): 6021-5

74. Chen L, Silapunt S, Migden MR. Sonidegib for the treatment of advanced basal cell carcinoma: a comprehensive review of sonidegib and the BOLT trial with 12-month update. Future Oncol. 2016;12(18):2095-105.

75. Minami H, Ando Y, Ma BB, Hsiang Lee J, Momota H, Fujiwara Y, Li L, Fukino K, Ito K, Tajima T, et al. Phase I, multicenter, open-label, dose-escalation study of sonidegib in Asian patients with advanced solid tumors. Cancer Sci. 2016;107(10):1477-83.

76. Abou-Alfa GK, Lewis LD, LoRusso P, Maitland M, Chandra P, Cheeti S, Colburn D, Williams S, Simmons B, Graham RA. Pharmacokinetics and safety of vismodegib in patients with advanced solid malignancies and hepatic impairment. Cancer Chemother Pharmacol. 2017;80(1):29-36.

77. Belvisi MG, Bundschuh DS, Stoeck M, Wicks S, Underwood S, Battram CH, Haddad el B, Webber SE, Foster ML: Preclinical profile of ciclesonide, a novel corticosteroid for the treatment of asthma. J Pharmacol Exp Ther 2005, 314(2):568-574.

78. Everson JL, Sun MR, Fink DM, Heyne GW, Melberg CG, Nelson KF, Doroodchi P, Colopy LJ, Ulschmid CM, Martin AA, et al. Developmental toxicity assessment of piperonyl butoxide exposure targeting sonic hedgehog signaling and forebrain and face morphogenesis in the mouse: an in vitro and in vivo study. Environ Health Perspect. 2019:127(10):107006.

79. Lauth M, Bergstrom A, Shimokawa T, Toftgard R. Inhibition of GLI-mediated transcription and tumor cell growth by small-molecule antagonists. Proc Natl Acad Sci U S A. 2007;104(20):8455-60.

80. Habib JG, O'Shaughnessy JA. The hedgehog pathway in triple-negative breast cancer. Cancer Med. 2016;5(10):2989-3006.
81. Merchant AA, Matsui W. Targeting Hedgehog--a cancer stem cell pathway. Clin Cancer Res. 2010;16(12):3130-40.

82. Amakye D, Jagani Z, Dorsch M. Unraveling the therapeutic potential of the Hedgehog pathway in cancer. Nat Med. 2013;19(11):1410-22.

83. Huang FT, Zhuan-Sun YX, Zhuang YY, Wei SL, Tang J, Chen WB, Zhang SN. Inhibition of hedgehog signaling depresses self-renewal of pancreatic cancer stem cells and reverses chemoresistance. Int J Oncol. 2012;41(5): 1707-14.

84. Liu S, Dontu G, Mantle ID, Patel S, Ahn NS, Jackson KW, Suri P, Wicha MS. Hedgehog signaling and Bmi-1 regulate self-renewal of normal and malignant human mammary stem cells. Cancer Res. 2006;66(12):6063-71.

85. Choi HS, Kim SL, Kim JH, Lee DS. The FDA-approved anti-asthma medicine ciclesonide inhibits lung cancer stem cells through Hedgehog signalingmediated SOX2 regulation. Int J Mol Sci. 2020;21(3):1014.

86. Casey D, Demko S, Shord S, Zhao H, Chen H, He K, Putman A, Helms W, Keegan P, Pazdur R. FDA approval summary: sonidegib for locally advanced basal cell carcinoma. Clin Cancer Res. 2017;23(10):2377-81.

87. Cazet AS, Hui MN, Elsworth BL, Wu SZ, Roden D, Chan CL, Skhinas JN, Collot $\mathrm{R}$, Yang J, Harvey $\mathrm{K}$, et al. Targeting stromal remodeling and cancer stem cell plasticity overcomes chemoresistance in triple negative breast cancer. Nat Commun. 2018:9(1):2897.

88. Ingram I. Vismodegib granted FDA approval for treatment of basal cell carcinoma; 2012.

89. Li W, Yang H, Li X, Han L, Xu N, Shi A. Signaling pathway inhibitors target breast cancer stem cells in triple-negative breast cancer. Oncol Rep. 2019; 41(1):437-46

90. Singh BN, Fu J, Srivastava RK, Shankar S. Hedgehog signaling antagonist GDC-0449 (Vismodegib) inhibits pancreatic cancer stem cell characteristics: molecular mechanisms. PLoS One. 2011;6(11):e27306.

91. De Jesus-Acosta A, Sugar EA, O'Dwyer PJ, Ramanathan RK, Von Hoff DD, Rasheed Z, Zheng L, Begum A, Anders R, Maitra A, et al. Phase 2 study of vismodegib, a hedgehog inhibitor, combined with gemcitabine and nabpaclitaxel in patients with untreated metastatic pancreatic adenocarcinoma. Br J Cancer. 2020;122(4):498-505.

92. Catenacci DV, Junttila MR, Karrison T, Bahary N, Horiba MN, Nattam SR, Marsh R, Wallace J, Kozloff M, Rajdev L, et al. Randomized phase Ib/II study of gemcitabine plus placebo or vismodegib, a Hedgehog pathway inhibitor, in patients with metastatic pancreatic cancer. J Clin Oncol. 2015;33(36): 4284-92.

93. Wu C, Hu S, Cheng J, Wang G, Tao K. Smoothened antagonist GDC-0449 (Vismodegib) inhibits proliferation and triggers apoptosis in colon cancer cell lines. Exp Ther Med. 2017;13(5):2529-36.

94. Berlin J, Bendell JC, Hart LL, Firdaus I, Gore I, Hermann RC, Mulcahy MF, Zalupski MM, Mackey HM, Yauch RL, et al. A randomized phase II trial of vismodegib versus placebo with FOLFOX or FOLFIRI and bevacizumab in patients with previously untreated metastatic colorectal cancer. Clin Cancer Res. 2013;19(1):258-67.

95. Fukushima N, Minami Y, Kakiuchi S, Kuwatsuka Y, Hayakawa F, Jamieson C, Kiyoi H, Naoe T. Small-molecule Hedgehog inhibitor attenuates the leukemia-initiation potential of acute myeloid leukemia cells. Cancer Sci. 2016;107(10):1422-9.

96. Chen JK, Taipale J, Young KE, Maiti T, Beachy PA. Small molecule modulation of Smoothened activity. Proc Natl Acad Sci U S A. 2002;99(22): 14071-6.

97. Li C, Du Y, Yang Z, He L, Wang Y, Hao L, Ding M, Yan R, Wang J, Fan Z GALNT1-mediated glycosylation and activation of sonic Hedgehog signaling maintains the self-renewal and tumor-initiating capacity of bladder cancer stem cells. Cancer Res. 2016;76(5):1273-83.

98. Kurebayashi J, Koike Y, Ohta Y, Saitoh W, Yamashita T, Kanomata N, Moriya T. Anti-cancer stem cell activity of a hedgehog inhibitor GANT61 in estrogen receptor-positive breast cancer cells. Cancer Sci. 2017;108(5):918-30.

99. Michy T, Massias T, Bernard C, Vanwonterghem L, Henry M, Guidetti M, Royal G, Coll JL, Texier I, Josserand V, et al. Verteporfin-loaded lipid nanoparticles improve ovarian cancer photodynamic therapy in vitro and in vivo. Cancers. 2019;11(11):1760

100. Su T, Yang $X$, Deng JH, Huang QJ, Huang SC, Zhang YM, Zheng HM, Wang Y, Lu LL, Liu ZQ. Evodiamine, a novel NOTCH3 methylation stimulator, significantly suppresses lung carcinogenesis in vitro and in vivo. Front Pharmacol. 2018;9:434.

101. Lopez-Aguilar E, Sepulveda-Vildosola AC, Rivera-Marquez H, Cerecedo-Diaz F, Valdez-Sanchez M, Villasis-Keever MA. Security and maximal tolerated 
doses of fluvastatin in pediatric cancer patients. Arch Med Res. 1999;30(2): 128-31.

102. Robison RL, Suter W, Cox RH. Carcinogenicity and mutagenicity studies with fluvastatin, a new, entirely synthetic HMG-CoA reductase inhibitor. Fundam Appl Toxicol. 1994;23(1):9-20.

103. Prado CM, Antoun S, Sawyer MB, Baracos VE. Two faces of drug therapy in cancer: drug-related lean tissue loss and its adverse consequences to survival and toxicity. Curr Opin Clin Nutr Metab Care. 2011;14(3):250-4

104. Song S, Xie M, Scott AW, Jin J, Ma L, Dong X, Skinner HD, Johnson RL, Ding S, Ajani JA. A novel YAP1 inhibitor targets CSC-enriched radiation-resistant cells and exerts strong antitumor activity in esophageal adenocarcinoma. Mol Cancer Ther. 2018;17(2):443-54.

105. Solmi M, Murru A, Pacchiarotti I, Undurraga J, Veronese N, Fornaro M, Stubbs B, Monaco F, Vieta E, Seeman MV, et al. Safety, tolerability, and risks associated with first- and second-generation antipsychotics: a state-of-theart clinical review. Ther Clin Risk Manag. 2017;13:757-77.

106. Zheng L, Xiang C, Li X, Guo Q, Gao L, Ni H, Xia Y, Xi T. STARD13-correlated ceRNA network-directed inhibition on YAP/TAZ activity suppresses stemness of breast cancer via co-regulating Hippo and Rho-GTPase/F-actin signaling. J Hematol Oncol. 2018;11(1):72.

107. Park JH, Shin JE, Park HW. The role of Hippo pathway in cancer stem cell biology. Mol Cells. 2018;41(2):83-92.

108. Giraud J, Molina-Castro S, Seeneevassen L, Sifré E, Izotte J, Tiffon C, Staedel C, Boeuf H, Fernandez S, Barthelemy P, et al. Verteporfin targeting YAP1/ TAZ-TEAD transcriptional activity inhibits the tumorigenic properties of gastric cancer stem cells. Int J Cancer. 2019;146(8):2255-67.

109. Song S, Ajani JA, Honjo S, Maru DM, Chen Q, Scott AW, Heallen TR, Xiao L, Hofstetter WL, Weston B, et al. Hippo coactivator YAP1 upregulates SOX9 and endows esophageal cancer cells with stem-like properties. Cancer Res. 2014;74(15):4170-82

110. Zhao S, Xu K, Jiang R, Li DY, Guo XX, Zhou P, Tang JF, Li LS, Zeng D, Hu L, et al. Evodiamine inhibits proliferation and promotes apoptosis of hepatocellular carcinoma cells via the Hippo-yes-associated protein signaling pathway. Life Sci. 2020;117424

111. Kim H, Yu Y, Choi S, Lee H, Yu J, Lee JH, Kim WY. Evodiamine eliminates colon cancer stem cells via suppressing Notch and Wnt signaling. Molecules. 2019;24(24):4520.

112. Qin J, Shi H, Xu Y, Zhao F, Wang Q. Tanshinone IIA inhibits cervix carcinoma stem cells migration and invasion via inhibiting YAP transcriptional activity. Biomed Pharmacother. 2018;105:758-65.

113. Zhao W, Wu M, Cui L, Du W. Limonin attenuates the stemness of cervical carcinoma cells by promoting YAP nuclear-cytoplasmic translocation. Food Chem Toxicol. 2019;125:621-8.

114. Tanaka K, Osada H, Murakami-Tonami Y, Horio Y, Hida T, Sekido Y. Statin suppresses Hippo pathway-inactivated malignant mesothelioma cells and blocks the YAP/CD44 growth stimulatory axis. Cancer Lett. 2017;385:215-24.

115. Koohestanimobarhan S, Salami S, Imeni V, Mohammadi Z, Bayat O. Lipophilic statins antagonistically alter the major epithelial-to-mesenchymal transition signaling pathways in breast cancer stem-like cells via inhibition of the mevalonate pathway. J Cell Biochem. 2018. https://doi.org/10.1002/ jcb. 27544

116. Yang CE, Lee WY, Cheng HW, Chung CH, Mi FL, Lin CW. The antipsychotic chlorpromazine suppresses YAP signaling, stemness properties, and drug resistance in breast cancer cells. Chem Biol Interact. 2019:302:28-35.

117. Al-Bari MA. Chloroquine analogues in drug discovery: new directions of uses, mechanisms of actions and toxic manifestations from malaria to multifarious diseases. J Antimicrob Chemother. 2015;70(6):1608-21.

118. Shi $T$, Yu XX, Yan $L$, Xiao HT. Research progress of hydroxychloroquine and autophagy inhibitors on cancer. Cancer Chemother Pharmacol. 2017; 79(2):287-94.

119. Brana I, Ocana A, Chen EX, Razak AR, Haines C, Lee C, Douglas S, Wang L, Siu LL, Tannock IF, et al. A phase I trial of pantoprazole in combination with doxorubicin in patients with advanced solid tumors: evaluation of pharmacokinetics of both drugs and tissue penetration of doxorubicin. Invest New Drugs. 2014;32(6):1269-77.

120. Dai S, Wang B, Li W, Wang L, Song X, Guo C, Li Y, Liu F, Zhu F, Wang Q, et al. Systemic application of 3-methyladenine markedly inhibited atherosclerotic lesion in ApoE(-/-) mice by modulating autophagy, foam cell formation and immune-negative molecules. Cell Death Dis. 2016;7(12): e2498.
121. Huang M, Tang SN, Upadhyay G, Marsh JL, Jackman CP, Srivastava RK, Shankar S. Rottlerin suppresses growth of human pancreatic tumors in nude mice, and pancreatic cancer cells isolated from $\mathrm{Kras}(\mathrm{G} 12 \mathrm{D})$ mice. Cancer Lett. 2014;353(1):32-40.

122. Nazio F, Bordi M, Cianfanelli V, Locatelli F, Cecconi F. Autophagy and cancer stem cells: molecular mechanisms and therapeutic applications. Cell Death Differ. 2019;26(4):690-702.

123. Auberger P, Puissant A. Autophagy, a key mechanism of oncogenesis and resistance in leukemia. Blood. 2017;129(5):547-52.

124. Liang DH, Choi DS, Ensor JE, Kaipparettu BA, Bass BL, Chang JC. The autophagy inhibitor chloroquine targets cancer stem cells in triple negative breast cancer by inducing mitochondrial damage and impairing DNA break repair. Cancer Lett. 2016;376(2):249-58.

125. Hao C, Liu G, Tian G. Autophagy inhibition of cancer stem cells promotes the efficacy of cisplatin against non-small cell lung carcinoma. Ther Adv Respir Dis. 2019;13:1753466619866097.

126. Rothe $K$, Porter V, Jiang X. Current outlook on autophagy in human leukemia: foe in cancer stem cells and drug resistance, friend in new therapeutic interventions. Int J Mol Sci. 2019;20(3):461.

127. Horne GA, Stobo J, Kelly C, Mukhopadhyay A, Latif AL, Dixon-Hughes J, McMahon L, Cony-Makhoul P, Byrne J, Smith G, et al. A randomised phase II trial of hydroxychloroquine and imatinib versus imatinib alone for patients with chronic myeloid leukaemia in major cytogenetic response with residual disease. Leukemia. 2020.

128. Hansen AR, Tannock IF, Templeton A, Chen E, Evans A, Knox J, Prawira A, Sridhar SS, Tan S, Vera-Badillo F, et al. Pantoprazole affecting docetaxel resistance pathways via autophagy (PANDORA): phase II trial of high dose pantoprazole (autophagy inhibitor) with docetaxel in metastatic castrationresistant prostate cancer (mCRPC). Oncologist. 2019;24(9):1188-94.

129. Feng S, Zheng Z, Feng L, Yang L, Chen Z, Lin Y, Gao Y, Chen Y. Proton pump inhibitor pantoprazole inhibits the proliferation, selfrenewal and chemoresistance of gastric cancer stem cells via the EMT/betacatenin pathways. Oncol Rep. 2016;36(6):3207-14.

130. Yang $H$, Zheng $Y$, Zhang $Y$, Cao Z, Jiang $Y$. Mesenchymal stem cells derived from multiple myeloma patients protect against chemotherapy through autophagydependent activation of NF-kappaB signaling. Leuk Res. 2017;60:82-8.

131. Kumar D, Shankar S, Srivastava RK. Rottlerin-induced autophagy leads to the apoptosis in breast cancer stem cells: molecular mechanisms. Mol Cancer. 2013;12(1):171.

132. Torti SV, Torti FM. Iron and cancer: more ore to be mined. Nat Rev Cancer. 2013;13(5):342-55.

133. El Hout M, Dos Santos L, Hamai A, Mehrpour M. A promising new approach to cancer therapy: targeting iron metabolism in cancer stem cells. Semin Cancer Biol. 2018;53:125-38.

134. Shah R, Shchepinov MS, Pratt DA. Resolving the role of lipoxygenases in the initiation and execution of ferroptosis. ACS central science. 2018; 4(3):387-96.

135. Conrad M, Kagan VE, Bayir H, Pagnussat GC, Head B, Traber MG, Stockwell BR. Regulation of lipid peroxidation and ferroptosis in diverse species. Genes Dev. 2018;32(9-10):602-19.

136. Stoyanovsky DA, Tyurina YY, Shrivastava I, Bahar I, Tyurin VA, Protchenko O, Jadhav S, Bolevich SB, Kozlov AV, Vladimirov YA, et al. Iron catalysis of lipid peroxidation in ferroptosis: regulated enzymatic or random free radical reaction? Free Radic Biol Med. 2019;133:153-61.

137. Recalcati S, Gammella E, Cairo G. Dysregulation of iron metabolism in cancer stem cells. Free Radic Biol Med. 2019;133:216-20.

138. Chanvorachote P, Luanpitpong S. Iron induces cancer stem cells and aggressive phenotypes in human lung cancer cells. Am J Physiol Cell Physiol. 2016;310(9):C728-39.

139. Raggi C, Gammella E, Correnti M, Buratti P, Forti E, Andersen JB, Alpini G, Glaser S, Alvaro D, Invernizzi P, et al. Dysregulation of iron metabolism in cholangiocarcinoma stem-like cells. Sci Rep. 2017;7(1):17667.

140. Schonberg DL, Miller TE, Wu Q, Flavahan WA, Das NK, Hale JS, Hubert CG, Mack SC, Jarrar AM. Karl RT et al: preferential iron trafficking characterizes glioblastoma stem-like cells. Cancer Cell. 2015;28(4):441-55.

141. Ishimoto T, Nagano O, Yae T, Tamada M, Motohara T, Oshima H, Oshima M, Ikeda T, Asaba R, Yagi H, et al. CD44 variant regulates redox status in cancer cells by stabilizing the $\mathrm{xCT}$ subunit of system $\mathrm{xC}(-)$ and thereby promotes tumor growth. Cancer Cell. 2011;19(3):387-400.

142. Liang $C$, Zhang $X$, Yang M, Dong $X$. Recent progress in ferroptosis inducers for cancer therapy. Adv Mater. 2019;31(51):e1904197. 
143. Mai T, Hamai A, Hienzsch A, Caneque T, Muller S, Wicinski J, Cabaud O, Leroy C, David A, Acevedo V, et al. Salinomycin kills cancer stem cells by sequestering iron in lysosomes. Nat Chem. 2017;9(10):1025-33.

144. Li L, Cui D, Ye L, Li Y, Zhu L, Yang L, Bai B, Nie Z, Gao J, Cao Y. Codelivery of salinomycin and docetaxel using poly(D,L-lactic-co-glycolic acid)poly(ethylene glycol) nanoparticles to target both gastric cancer cells and cancer stem cells. Anticancer Drugs. 2017;28(9):989-1001.

145. Antoszczak M. A medicinal chemistry perspective on salinomycin as a potent anticancer and anti-CSCS agent. Eur J Med Chem. 2019;164:366-77.

146. Zhao Y, Zhao W, Lim YC, Liu T. Salinomycin-loaded gold nanoparticles for treating cancer stem cells by ferroptosis-induced cell death. Mol Pharm. 2019;16(6):2532-9.

147. Versini A, Colombeau L, Hienzsch A, Gaillet C, Retailleau P, Debieu S, Muller $S$, Caneque T, Rodriguez R: Salinomycin derivatives kill breast cancer stem cells via lysosomal iron targeting. Chemistry 2020. https://doi.org/10.1002/ chem.202000335.

148. Turcu AL, Versini A, Khene N, Gaillet C, Caneque T, Muller S, Rodriguez R. DMT1 inhibitors kill cancer stem cells by blocking lysosomal iron translocation. Chemistry 2020. https://doi.org/10.1002/chem.202000159.

149. Basuli D, Tesfay L, Deng Z, Paul B, Yamamoto Y, Ning G, Xian W, McKeon F, Lynch $\mathrm{M}$, Crum CP, et al. Iron addiction: a novel therapeutic target in ovarian cancer. Oncogene. 2017;36(29):4089-99.

150. Buccarelli M, Marconi M, Pacioni S, De Pascalis I, D'Alessandris QG, Martini M, Ascione B, Malorni W, Larocca LM, Pallini R, et al. Inhibition of autophagy increases susceptibility of glioblastoma stem cells to temozolomide by igniting ferroptosis. Cell Death Dis. 2018;9(8):841.

151. Chen GQ, Benthani FA, Wu J, Liang D, Bian ZX, Jiang X. Artemisinin compounds sensitize cancer cells to ferroptosis by regulating iron homeostasis. Cell Death Differ. 2020;27(1):242-54.

152. Cao L, Duanmu W, Yin Y, Zhou Z, Ge H, Chen T, Tan L, Yu A, Hu R, Fei L, et al. Dihydroartemisinin exhibits anti-glioma stem cell activity through inhibiting p-AKT and activating caspase-3. Pharmazie. 2014;69(10):752-8.

153. Subedi A, Futamura Y, Nishi M, Ryo A, Watanabe N, Osada H. Highthroughput screening identifies artesunate as selective inhibitor of cancer stemness: involvement of mitochondrial metabolism. Biochem Biophys Res Commun. 2016:477(4):737-42.

154. Eling N, Reuter L, Hazin J, Hamacher-Brady A, Brady NR. Identification of artesunate as a specific activator of ferroptosis in pancreatic cancer cells. Oncoscience. 2015;2(5):517-32.

155. Su Y, Zhao B, Zhou L, Zhang Z, Shen Y, Lv H, AlQudsy LHH, Shang P. Ferroptosis, a novel pharmacological mechanism of anti-cancer drugs. Cancer Lett. 2020;483:127-36.

156. Sadhukha T, Niu L, Wiedmann TS, Panyam J. Effective elimination of cancer stem cells by magnetic hyperthermia. Mol Pharm. 2013;10(4):1432-41.

157. Bullivant JP, Zhao S, Willenberg BJ, Kozissnik B, Batich CD, Dobson J. Materials characterization of feraheme/ferumoxytol and preliminary evaluation of its potential for magnetic fluid hyperthermia. Int J Mol Sci. 2013;14(9):17501-10.

158. Chen B, Xing J, Li M, Liu Y, Ji M. DOX@ferumoxytol-medical chitosan as magnetic hydrogel therapeutic system for effective magnetic hyperthermia and chemotherapy in vitro. Colloids Surf B Biointerfaces. 2020;190:110896.

159. Antoszczak M. A comprehensive review of salinomycin derivatives as potent anticancer and anti-CSCs agents. Eur J Med Chem. 2019;166:48-64.

160. Zhao B, Li X, Wang Y, Shang P. Iron-dependent cell death as executioner of cancer stem cells. J Exp Clin Cancer Res. 2018:37(1):79.

161. Azad GK, Tomar RS. Ebselen, a promising antioxidant drug: mechanisms of action and targets of biological pathways. Mol Biol Rep. 2014;41(8):4865-79.

162. Zhang Z, Kodumuru V, Sviridov S, Liu S, Chafeev M, Chowdhury S, Chakka N, Sun J, Gauthier SJ, Mattice M, et al. Discovery of benzylisothioureas as potent divalent metal transporter 1 (DMT1) inhibitors. Bioorg Med Chem Lett. 2012;22(15):5108-13.

163. Stepanovic A, Nikitovic M. Severe hematologic temozolomide-related toxicity and lifethreatening infections. J BUON. 2018;23(1):7-13.

164. Luo Y, Che MJ, Liu C, Liu HG, Fu XW, Hou YP. Toxicity and related mechanisms of dihydroartemisinin on porcine oocyte maturation in vitro. Toxicol Appl Pharmacol. 2018;341:8-15.

165. Li H, Xu K, Pian G, Sun S. Artesunate and sorafenib: combinatorial inhibition of liver cancer cell growth. Oncol Lett. 2019;18(5):4735-43.

166. Slezakova S, Ruda J: Anticancer activity of artemisinin and its derivatives. Anticancer Res 2017, 37(11).
167. Kaittanis C, Shaffer TM, Ogirala A, Santra S, Perez JM, Chiosis G, Li Y, Josephson L, Grimm J. Environment-responsive nanophores for therapy and treatment monitoring via molecular MRI quenching. Nat Commun. 2014;5: 3384.

168. Nguyen KL, Yoshida T, Kathuria-Prakash N, Zaki IH, Varallyay CG, Semple SI, Saouaf R, Rigsby CK, Stoumpos S, Whitehead KK, et al. Multicenter safety and practice for off-label diagnostic use of ferumoxytol in MRI. Radiology. 2019;293(3):554-64.

169. Shepshelovich D, Rozen-Zvi B, Avni T, Gafter U, Gafter-Gvili A. Intravenous versus oral iron supplementation for the treatment of anemia in CKD: an updated systematic review and meta-analysis. American journal of kidney diseases : the official journal of the National Kidney Foundation. 2016;68(5): 677-90

170. Miller RC, Petereit DG, Sloan JA, Liu H, Martenson JA, Bearden JD 3rd, Sapiente R, Seeger GR, Mowat RB, Liem B, et al. N08C9 (Alliance): a phase 3 randomized study of sulfasalazine versus placebo in the prevention of acute diarrhea in patients receiving pelvic radiation therapy. Int J Radiat Oncol Biol Phys. 2016;95(4):1168-74

171. Hangauer MJ, Viswanathan VS, Ryan MJ, Bole D, Eaton JK, Matov A, Galeas J, Dhruv HD, Berens ME, Schreiber SL, et al. Drug-tolerant persister cancer cells are vulnerable to GPX4 inhibition. Nature. 2017;551(7679):247-50.

172. Viswanathan VS, Ryan MJ, Dhruv HD, Gill S, Eichhoff OM, Seashore-Ludlow B, Kaffenberger SD, Eaton JK, Shimada K, Aguirre AJ, et al. Dependency of a therapy-resistant state of cancer cells on a lipid peroxidase pathway. Nature. 2017;547(7664):453-7.

173. Jung Y, Park H, Zhao HY, Jeon R, Ryu JH, Kim WY. Systemic approaches identify a garlic-derived chemical, Z-ajoene, as a glioblastoma multiforme cancer stem cell-specific targeting agent. Mol Cells. 2014;37(7):547-53.

174. Kim TY, Han HS, Lee KW, Zang DY, Rha SY, Park YI, Kim JS, Lee KH, Park SH, Song EK, et al. A phase I/II study of poziotinib combined with paclitaxel and trastuzumab in patients with HER2-positive advanced gastric cancer. Gastric Cancer. 2019;22(6):1206-14

175. Zhu Y, Warin RF, Soroka DN, Chen H, Sang S. Metabolites of ginger component [6]-shogaol remain bioactive in cancer cells and have low toxicity in normal cells: chemical synthesis and biological evaluation. PLoS One. 2013;8(1):e54677.

176. Lee H, Kim JW, Choi DK, Yu JH, Kim JH, Lee DS, Min SH. Poziotinib suppresses ovarian cancer stem cell growth via inhibition of HER4-mediated STAT5 pathway. Biochem Biophys Res Commun. 2020;526(1):158-64.

177. Ray A, Vasudevan S, Sengupta S. 6-Shogaol inhibits breast cancer cells and stem cell-like spheroids by modulation of Notch signaling pathway and induction of autophagic cell death. PLoS One. 2015;10(9):e0137614.

178. Dreesen O, Brivanlou AH. Signaling pathways in cancer and embryonic stem cells. Stem Cell Rev. 2007:3(1):7-17.

\section{Publisher's Note}

Springer Nature remains neutral with regard to jurisdictional claims in published maps and institutional affiliations.

Ready to submit your research? Choose BMC and benefit from:

- fast, convenient online submission

- thorough peer review by experienced researchers in your field

- rapid publication on acceptance

- support for research data, including large and complex data types

- gold Open Access which fosters wider collaboration and increased citations

- maximum visibility for your research: over $100 \mathrm{M}$ website views per year

At $\mathrm{BMC}$, research is always in progress.

Learn more biomedcentral.com/submissions 